\title{
The Impact of Supply-Chain Management Capabilities on Business Performance in Egyptian Industrial Sector
}

\author{
Assrar Sabry $^{1}$ \\ ${ }^{1}$ Faculty of Commerce, Alexandria University, Egypt \\ Correspondence: Assrar Sabry, Faculty of Commerce and Business Administration, Alexandria University, \\ Egypt. E-mail: assrarsabry@yahoo.com
}

Received: March 10, 2015

Accepted: April 16, 2015

Online Published: May 25, 2015

doi:10.5539/ijbm.v10n6p251

URL: http://dx.doi.org/10.5539/ijbm.v10n6p251

\begin{abstract}
The aim of the research is to add to the knowledge of supply chain management practices by exploring the relationships among three constructs of supply chain management capabilities (SCMC) including outside-in process capabilities (OIC), inside-out process capabilities (IOC) and spanning process capabilities (SC) as the concepts proposed by Day (1994) and confirmed by the empirical studies provided through Tracey, Fite and Sutton (2004) and Tracey, Lim and Vonderembse (2005) through developing and testing a research framework of supply chain management capabilities and its impact on business performance construct. Based on the literature review, a proposed research model and five hypotheses are developed. The results indicated that there are significant positive correlation between the three constructs of supply chain management capabilities and business performance. Hypotheses (H2 and $\mathrm{H} 4)$ are supported and accepted, hypotheses ( $\mathrm{H} 1$ and $\mathrm{H} 3)$ are supported but partially accepted, and hypothesis (H5) is rejected; therefore, the overall obtained results of testing the research hypotheses supported the proposed relations in the research.
\end{abstract}

Keywords: supply chain management (SCM) capabilities, spanning process capabilities, outside-in process capabilities, inside-out process capabilities, business performance

\section{Introduction}

Organizations are faced with an array of challenges as they strive to compete in today's dynamic global markets. To remain competitive, organizations must recognize the importance of supply chain practices that not only improve their own performances, but also create values by means of optimizing customer satisfaction and helping to significantly improve the overall performance of a business (Cook, Heizer, \& Sengupte, 2011). Kumar and Nambirajan (2013) explain that supply chain management (SCM) is a complex subject, which is an important determinant of the success or failure of any manufacturing enterprise. It is absolutely essential for executives of manufacturing enterprises to be thoroughly aware of all the essential components of supply chain management, and to understand the impact that it might exert on the overall efficiency of the organisation. This knowledge will enable them to focus on these variables which add values to organisations and even support the significance of SCM.

Nowadays, business is more challenging, and many of the companies increase their focus on creating the best value to the targeted customer. The center of business concern is to provide valuable products or services which can meet the customer's need (Sukati, Abdul Hamid, \& Baharun, 2013). SCM allows suppliers, manufacturers, distributors, and customers to integrate their operations in order to reduce costs and response time to the customer. SCM is the integration of key business processes including the customary logistics activities of warehousing, inventory control, transportation management, and the non-traditional logistics activities including procurement, production support, packaging, and the processing of orders. SCM assesses the operational strategies that impact the purchasing, production, logistics management, and also analyzes the entire flow of goods and services in the supply chain to improve profitability (Weeks \& Mileski, 2013).

With the increasing importance of outsourcing in today's global market, SCM is usually seen as a way to improve competitive performance by integrating the internal functions of a company and linking them with the external operations of suppliers, customers, and other channel members (Tutuncu \& Kucukusta, 2008). SCM is not a new concept for manufacturing companies since SCM has been implemented in the system for a long time. Kotzab, Teller, Grant, and Friis, (2014) mentioned that (Schnetzler \& Schonsleben, 2007) defined SCM as the 
coordination of strategic and long term cooperation among co-makers in the total supply chain for the development and production of products, both in production and procurement, but (Heizer \& Render, 2014) reported that SCM refers also to manufacturing processes required to transform goods from raw materials into final products based on offering a support function to operations strategy.

In Giovanni (2009), the literature on supply chain broadly investigates the links between SC implementation, management, and performance. (Lamberton et al., 1998) and numerous studies (e.g., Li et al., 2005; Trkman \& Groznik, 2006) show how SC integrates and coordinates firms' activities improving overall performance and customer satisfaction. Supply chain is a linked set of resources and processes that begins with the sourcing of raw materials and extends through the delivery of end items to the final customer. According to Noraini and Saifudin (2014) (as in Moskdanian \& Molahosseini, 2013) reported that SCM is one of important variable in measuring the performance. They found, there is a positive and strong relationship between SCM and performance to coordinate the flow of material from supplier to customer throughout the value stream; (e.g., Bannet and Klug, 2012) in their studies concluded that SCM is a new form of criteria for companies to evaluate the performance between the company and supplier. Prajogo and Olhager (2012) also believed that improvements in logistics integration contribute to the increase in operational benefits. However, the research is limited in SCMC and business performance, and due to this research gap, this paper is interested in studying this relationship. This research focuses on the relationship between business performance and three constructs of SCM capabilities: outside-in process capabilities, inside-out process capabilities and spanning process capabilities. Knowing that in the logistics field, increased attention has been given to these relationships through (Day, 1994; Tracey et al., 2004; Tracey et al., 2005; Sengupta, Heiser, \& Cook, 2006; Arshinder \& Deshmukh, 2008; Martin \& Patterson, 2009; Blomqvist, 2010; Sukati et al., 2013; Mekel, Anantadjaya, \& Lahindah, 2014; Ann I, Victoria, \& Ukpere, 2014).

\subsection{Research Objective}

The aim of the research is to test a model of the relationships among outside-in process capabilities, inside-out process capabilities and spanning process capabilities, and business performance. The research objectives are structured as follows:

The first objective is to establish the extent of supply chain management capabilities implementation in a sample of companies in the Egyptian industrial sector.

The second objective is to determine the impact of supply chain management capabilities on business performance in a sample of companies in the Egyptian industrial sector.

\subsection{Research Problem}

Based on (Martin et al., 2009; Lawson, Cousins, Handfield \& Petersen, 2009), recent works such as (Bozarth et al., 2009; Cai et al., 2009) have shown a clear interest in investigating the impact of SCM practices on business and operational performances. In spite of the successful application of these studies, the study of the relationship between the SCMC and business performance, proposed by (Day, 1994) and tested by (Tracey et al., 2004; Tracey et al., 2005), didn't achieve enough interest from the researchers. Therefore, the current research is developed to cover this gap through answering the following questions:

1) To what extent do the outside-in process capabilities' dimensions and the spanning capabilities' dimensions influence the inside-out process capabilities' dimensions in a sample of companies in the Egyptian industrial sector?

2) To what extent do the spanning capabilities' dimensions influence the outside-in process capabilities' dimensions in a sample of companies in the Egyptian industrial sector?

3) To what extent do the spanning process capabilities' dimensions and the inside-out capabilities' dimensions influence the business performance dimensions in a sample of companies in the Egyptian industrial sector?

\subsection{Research Importance}

Despite the increasing amount of attention paid to supply chain management (SCM) practices by practitioners and academicians, failures in effectively implementing SCM practices still exist (Shang \& Marlow, 2005; Green Jr, Whitten, \& Inman, 2008; Kempkes, Koberstein, \& Suhl, 2010; Meisel, Rei, Gendreau, \& Bierwirth, 2011; Elkhouly, Ismail, Husien, \& El Shazely, 2012; Ann I et al., 2014; Kumar \& Nambirajan, 2014). The reasons of the unsuccessful implementation of SCM can be attributed to a variety of reasons. For instance, research studies identifying different dimensions of supply chain management constructs seem to differ in their approach. Yet, there have been some studies that provide a framework for identification of different dimensions under the 
supply chain construct such as (Day, 1994; Tracey et al., 2004; Tracey et al., 2005).

1) The current research will test again the (Tracey et al., 2005) model to support the theoretical framework of this model in the SCMC by developing additional data from another region and other industries.

2) This research will refine the measurement of the model's constructs and the scales that are developed and included in the components of the dimensions in study of (Tracey et al., 2005) so that findings can be generalized.

3) This research designates the traditional physical distribution SCM/ logistics processes that transpire after the raw materials/ component parts have been transformed into the finished product as inside-out capabilities: packaging, finished goods warehousing, inventory control-outbound, and outbound transportation, these activities are mostly invisible to end-users but are critical elements of SCMC.

4) There has been a lack of the studies demonstrating the relationship between SCMC and the business performance (Tracey et al., 2005; Tutuncu et al., 2008; Manders, 2009), so this research seeks to address this gap in SCM literature.

\subsection{Background and Previous Research}

As the concepts proposed by Day (1994) and confirmed by the empirical studies provided through Wisner (2003); Lockamy and McCormack (2004); Tracey et al., (2004) and Tracey et al., (2005), supply-chain management capabilities are classified into three constructs:

First: Outside-in capabilities which refer to the group of capabilities that enables the company to compete by forecasting and acting on changes in markets through the development of sound relations with suppliers, channel members, and customers on activities such as inbound transportation, material warehousing, inventory control-inbound, and production support.

Second: Inside-out capability, which refer to those internal capabilities that enable a firm to exploit opportunities in the environment, such as packaging, finished goods warehousing, inventory control-outbound and outbound transportation.

Third: Spanning capabilities refer to the processes that support the anticipated needs of patrons fulfilled by the business, such as purchasing, customer order processing, strategy development, and information dissemination.

These three constructs affect the business performance through the following four dimensions: perceived product value, customer loyalty, market performance, and financial performance.

\subsection{Theoretical Background}

As the SCM is a contemporary issue of great importance in business and academic areas, it is still lacking some systematization in its terminology. The analyzed studies used a large number of variables in order to compose their constructs. These variables are not usually the same in different studies. Thus, a systematization of terminology and variables of SCM is necessary in order to improve the measurement of the constructs. Therefore, this research aims to develop a synthesis of the literature in the three constructs of the SCM capabilities to provide a conceptual foundation for the model. Then, develop the logic of the substantive relationships among the research constructs of the model and state hypotheses.

\subsubsection{The First Construct: Outside-in Capabilities}

Businesses today often have tangible assets, but lack the underlying capabilities required to be successful. Day (1994) defined capabilities as complex bundles of skills and accumulated knowledge exercised through organizational processes that enable firms to coordinate their activities and make better use of their assets. Capabilities are difficult to replicate and assist in creating unique competitive advantage. SCM is a philosophy that views a business as an interrelated entity with many parts that seeks to integrate all aspects of the chain's resources to provide superior value to customers. Effective SCM thus can be considered a capability that can help solve the problems inherited by modern manufacturing organizations.

\subsubsection{Inbound Transportation}

Tseng, Taylor, and Yue (2005) stated, as suggested by various prior studies (e.g., Ampuja et al., 2002; Peck et al., 2003), that the key element in a logistics chain is the transportation system, which joins the separated activities. Transportation inbound logistics is a critical component of the supply chain that is often overlooked and it has always been considered as a marginal activity within supply chains. Transport system is the most important economic activity among the components of business logistics systems. It provides the physical link through the movement and storage of materials for production, and outbound logistic through the movement and storage of 
finished goods to the customer. Around one third to two thirds of the expenses of enterprises' logistics costs are spent on transportation. The cost of transportation, on average, is accounted for $6.5 \%$ of market revenue and $44 \%$ of logistics costs. Production or manufacturing plants required the assembly of materials, components, and supplies, with or without storage, processing and material handling within the plant and plant inventory. Rodrigues, Augusto, Damian, Thomas, Mohamed, and Anthony (2008), concluded that little research has been undertaken including transport operations as a strategic factor of the supply chain. Manufacturing uncertainty impacts on transport operations by having problems with quality control (e.g., Van der Vorst \& Beulens, 2002, Mason-Jones \& Towill, 1998, Geary et al., 2002), ineffective manufacturing scheduling (Childerhouse \& Towill 2003, McKinnon \& Ge, 2004), loss or damage of materials in the shipping operation and capacity technology restrictions (Morash \& Clinton 1997).

Ineffective supply chain management can also produce a lot of issues within transport such as excessive dispersion and lack of flexibility (Beier, 1989; Cavinato, 2004) in the supply chain infrastructure which can limit transport optimization. Insufficient planning of supply chain strategies (Childerhouse \& Towill, 2003) and conflicting objectives between different market segments (Christopher \& Lee, 2004) can lead to low level of transport performance. Tracey (2003) suggested that both the inbound and outbound facets of transportation are critical to the overall supply chain performance, that customer value can be created, and that firm performance can be enhanced by optimizing inbound and outbound logistics functions. He also demonstrated empirically that proper alignment of logistics with manufacturing can result in higher quality and reduced costs. Logistics can also boost supply chain optimization when confronted with uncertain demand. Intelligent administration of lower levels of inventory, safety stock, transportation mode and carrier selection, data systems, forecasting, subcontracting, and/or facility location issues can assist in meeting changing customer demand efficiently. Outstanding execution regarding transportation is at the foundation of overall logistics and SCM success. It is possible to manage it proactively in today's deregulated environment to provide a competitive advantage to the chain. Tracey et al (2004) stated that excessive dispersion and lack of flexibility (Cavinato, 2004), insufficient planning of supply chain strategies (Childerhouse \& Towill 2003) and conflicting objectives between different market segments (Christopher and Lee, 2004) can lead to low level of transportation performance.

\subsubsection{Material Warehousing}

Kempkes et al (2010) reported that the industrial companies require thousands of parts and items, thus logistic operations play a critical role to fulfill these demands of parts and items needed to prepare daily schedules to match the changing production plans. In addition, the managers responsible for managing the material requirement planning are focused on filling orders rapidly and efficiently, improving the levels of inventory and reducing the time to market, Martin et al (2009) conducted a survey that consists of 143 managers from purchasing, logistics and material departments to identify the performance measures used in their companies that helped to adopt SCM practices. The results indicated that the SCM practices are positively associated with the indicators of both the levels of inventory (raw material, final product and storage volume) and the cycle time (inventory turnover and order fulfillment). The results found that there is a relationship between the efficiency of inbound operations and the ideal time needed to receive the material and to store. In addition, the types and the volumes of orders that are processed and the number of stock-keeping units are important considerations in determining the requirements of the layout process, the selection of equipment, and the production processes.

$\mathrm{Gu}$, Goetschalckx and McGinnis (2007) mentioned that the previous researches has focused strongly on receiving, storage, order picking operations and shipment in managing the material warehousing. But that study has found that storage capacity, space utilization, and picking efficiency have a high impact on measuring the warehousing performance. They disclosed that the decisions regarding to the warehousing processes on the operational level include two activities which help to flow the materials coming into the warehouse belong to the inbound logistics process such as receiving (the process of unloading, checking quality and quantity, and dissembling or repacking items for storage); and order picking (retrieving items from their storage locations and transporting them either to a sorting process or straight to the shipping area) besides, the nature of the products and the different number of items requested in each order. The choice of a good storage system and the order picking system are determined based on the physical characteristics of the goods, their packaging, and the composition of its outgoing items.

As mentioned by (Zailani, Dahalan, Hamdani, \& Fernando, 2009), it is widely accepted literature that SCM is important for material and information flows relating to the transformation of the materials into value added products, the delivery of the finished products through appropriate channels to customers and markets so as to maximize customer value and satisfaction. Increasing the competition has forced the organizations to be creative in their strategic efforts and to learn how to improve the ways to serve their customers. Therefore, many 
organizations seek to have competitive capabilities that enable them to exceed the customers' perceptions, enhance the market and the financial performance. The results found that adopting effective system of information technology in supply chain allows rich information exchange, quick and reliable data availability, and easy access to business partners. In addition, forecasting the materials has a positive influence on adopting IT in supply chain and thus influence on the warehousing systems of these materials.

\subsubsection{Inventory Control-Inbound}

Lwiki, Ojera, Mugenda, Wachira (2013) pointed that controlling the inventory management is a crucial function in the industrial companies due to a significant blend of reasons. First, mismanagement of inventory threatens a firm's viability, consumes physical space, creates financial burden, and increases the possibility of damage, spoilage and loss (as in Sprague \& Wacker, 1996). Second, reducing inventories often disrupts manufacturing operations and increases the likelihood of poor customer service (as in Womack et al., 1990). Ng'ang'a (2013) found that there are significant challenges related to daily recording of each available item in the storehouse such as the slowness of operations of the inventory control systems, data integrity, security and the accuracy of data about the inventory. The results found that $46.9 \%$ of the respondents felt that data may have been misplaced or lost. While $25 \%$ of the respondents found that the inventory control system used may lead to a high risk due to incorrect inventory entries. In addition, they concluded that, some very important researches has already addressed several aspects regarding the inventory control such as Dobler and Burt (2006), who found that the inventory alone represents as much as $30 \%$ of the invested capital. Whereas, Sunil and Sameer (1998), argued that to compete effectively in a global marketplace, the firms must understand the issues of inventory control that align with their purchasing system from the diverse environments in which they operate, Whilst Susan and Michael (2000) reported that the accuracy of inventory records is necessary to achieve a set of factors such as improving the customer service, identifying the replenishment of individual items, ensuring the material availability that meets the projected demand, and analyzing inventory levels to dispose of excess inventory.

According to Mogere, Oloko, and Okibo (2013), the inventory management needs a proper control system because it is one of the largest assets of the company. Inventory investment and its control systems make up a big percentage of the total budget, this required from the managers of these firms to pay a crucial efforts in building effective and efficient strategies that enhance handling the inventory and improve the operational performance (as in Salawati, Tinggi, \& Kadri, 2012; Ondiek \& Odera, 2012; Kagira, Kimani, \& Kagwithi, 2012). Both Stevenson (2006) and Kagira et al (2012) found that the inventory represents a significant portion of the current assets at any industrial companies and causes many problems such as fluctuating inventories, deficient information sharing, insufficient market data, deficient forecasts, and low utilization that will lead to significant losses and istage in the supply chain. The reasons for these problems are due to inadequate coordination of operations, variability of daily deliveries, varying the intervals between receiving the purchased parts and transforming them into final products, unreliable and inconsistent processing. If the companies want to excel in competitive environment, they must design and operate materials management that enable them to determine and maintain an optimum level of investment in inventory in order to achieve the required operational performance.

Augustine and Agu (2013) stated that materials and supplies of inventory that pushes the companies into either sale or to provide inputs or supplies to the production process. An inventory system is the set of policies and controls that monitors levels of inventory and determines what levels should be maintained, when stock should be replenished, and how large orders should be delivered. Managing the inventory effectively requires planning and control of inventory at optimum levels and requires determining the quality of a reasonable inventory to meet the needs of the processing or production on a scheduled basis, to satisfy customer orders, to protect the firm from the uncertainties in demand, to enable the specialization in manufacturing, to act as a buffering system between critical interfaces within the supply chain, and to ensure timely delivery of raw materials to the factory. If the inventory is not adequately maintained, production wouldn't meet the aspirations of customers thus leading to the loss of firm' revenue.

Whereas, Martin et al. (2009) proposed three indicators for measuring inventory systems such as operating cycle time, inventory turnover and order fulfilment that required disseminating the information within the members of the whole supply chain with no restrictions. Besides, the results found that the inventory systems have a positive impact on operation cycle time and have indirect impact on the financial performance. Naude and Badenhorst-Weiss (2011) concluded that the failure to estimate demand accurately and the failure of sharing the information among supply chain members can result in bloated inventory levels that may be caused by the cumulative effect of poor information cascading up through a supply chain. Poor demand data forces the supplying firm to carry additional inventory to account for uncertainty, and frequently the inventory levels in the supply chain are increased. Rodrigues et al. (2008) added that bloated inventory levels may be caused by the 
high level of unnecessary inventories, the lack of relevant inventories, making wrong orders of materials, increasing the number of emergency orders, the lack of engagement of the key customers, frequent changes, the absence of control related to priority orders, and the conflict of the schedules for the operating times.

Mekel et al. (2014) showed that the error in the required quantity orders has a negative value because the forecasted average quantity of the demand is higher than the quantity demanded in the past thus the accuracy of forecasting can lead the company to produce an amount of products neither less nor more than the amount produced in the past. In addition, the results found that the company should own the maximum level of safety stock in anticipation of the "stock out" due to delays, errors in ordering the raw materials, or receiving the emergent orders during the period of the lead time.

The recent study of Ann I et al. (2014) proposed three indicators for measuring the flexibility in managing inventory control such as storage systems, retrieval of materials, and effective strategies for sales. The results showed that these indicators have a positive impact on improving the business performance, reducing the operational cost and also revealed that implementing operational feasibility, maximizing the utility from inventory control management and using the effectiveness technique for calculating the cost of inventory are important to enhance the return on investment.

\subsubsection{Production Support}

According to Lee, Jang, Kim, Kim and Lee (2008) supply chain managers provide production support and ensure that key materials are available when needed by managing the flow of materials, information and services. SCM processes help to reduce the uncertainty and risks in the supply chain, which will allow a company to reap the benefits of a leaner operation, to ensure that the supply keeps flowing consistently as needed, to make sure that product for supply is kept flowing to meet demand, and to coordinate the shipment of raw materials and finished products. The relationships between firms and their suppliers are based on six factors in the following order: strategic collaboration with main suppliers, involvement main suppliers in product development, planning of production and management inventory, developing supplier response for ordering processing system, developing business network that guarantee the trust among partners, and exchanging the business information between them. Hamzeh, Tommelein, Ballard and Kaminsky (2007) developed a logistic system to support project-based production needs. Construction schedules assume a certain start date and duration for site activities based on the use of information systems. The variation in construction schedules results in relative variation in material. Variations in supply for materials and services affect progress on construction projects due to fluctuations in capacity, market status; delivery times, product availability and delivery lead time. With highly fluctuating demand for products, inventory management has become an important element, especially for safety stock itself. There are four components for calculating safety stock: forecast demand, service level, lead time and also actual demand. It is necessary to achieve accurate forecasting so that the company can determine the quantities that should be purchased, produced, and shipped.

Meisel et al. (2011) mentioned that "productions support" means describing the components of the final products through using a multi-product bill of material (PPBOM). It has a positive impact on the lead time of the required orders at the different stages of production process.

Mekel et al. (2014) concluded that the lead time elapsed from the receipt of customer's order until the delivery of finished goods to the customer should be determined to identify the re-ordering point and safety stock levels in anticipation of stock out in the warehouse due to the long lead time. The efficiency of product line aims to identify the ratio between the assigning task time and the operating cycle time inorder to add value to the product. The paper provided by Senapati, Mishra, Routra and Bisis (2012) proposed some key factors for production support that should be considered for reducing the lead time of inventory such as demand rate, order quantity, quality of items, reorder point and safety stock. The results found that the discount rate, the level of inflation and the time value of money have a positive impact on reducing safety stock, reducing the loss caused by stock out, improving the service level to the customer, and increasing the competitive ability of the firms.

In addition, the results showed that under cost and time considerations, a firm can apply a variety of means to reduce the lead time in order to satisfy customer's demands by crashing the setup transportation time, or by the increasing the production rate. Whilst, Sukati et al. (2013) found that the performance of supplier is measured using the lead time, the quality of products and services, and the reliability of delivery time. Thus, the existence of database integrated to the departments of production, logistics and distribution of products can help their supplier's easy access to the key operational data. On other side, the integration between the internal practices across different activities in the company such as, evaluating the inventory information, identifying the status of 
inventory at the right time by using the planning system to the marketing and production based on computerized system, and by depending on the integration between the information system and the production processes.

\subsubsection{The second Construct: Inside-Out Capabilities}

The firm's logistics capabilities perceived as one way to exceed customers' expectations, and to enhance the market and the financial performance. Based on Day (1994), Tracey et al (2005) suggested that the processes performed to transform the raw materials and the component parts into the finished product are called inside-out capabilities construct that consists of packaging, finished goods warehousing, inventory control-outbound, and outbound transportation. These activities are mostly invisible to end users but they represent as critical elements of SCM, particularly when the products on the shelves have a short life cycle.

\subsubsection{Packing}

As mentioned by Mukai (2014) the industrial companies consider packaging as a way to attract customers to new and existing brands. Packages used design, colors, shapes, pictures, and materials to try to influence the consumer's perceptions, to protect the materials and the products through promoting and transporting them. This study revealed that the relationship between components of designing, the labeling of packaging and the product characteristics is still unclear. In addition, the results supported that packaging is an important process at the end of the product line inside the plant, during storage, during handling and distributing the products, during transportation, and during the consumption process. Silayoi et al (2007) investigated the role of packaging food products for communicating with customers in Finland. The results showed that some consumers are mostly oriented toward the visual aesthetics, while a small segment of consumers focuses on product details on the label and their perceptions about the technology used for packaging which plays the most important role in the overall consumer's likelihood to buy the product. Whilst, this result contradicted with the results provided by (D'Souza et al., 2006) who found that the customers' perception toward the packaging of the products is based on their past experience but not based on the green products, the product labels, or the product ingredients.

Whilst, Abdalkrim and AL-Hrezat (2013) found that there is no significant impact of the role of packaging on consumer's perception of product quality at the point of purchase especially in protecting the products, facilitating the storage, and reducing environmental damage. Based on the study provided by (Wang, Hong, Qian, Wang \& Lu, 2014), Chaudhary (2014) aims to investigate the influence of the subsequent factors role of packaging (such as protection of product, promotion of product, facilitation of storage, convenience of product, facilitation of use and cut back environmental damage) on consumer's perception of the product quality at the time of purchase in some of Indian companies. The results found that there is a significant relationship between the role of packaging the products and facilitating the storage and the convenience of products on consumer's perception of product quality at the time of purchase. In addition, the results found that the style used for packaging the products has a strong impact on consumers' perception. Dhurup, Mafini, Dumasi (2014) stated that the most recent researches such as (Couste, Ros, \& Partal, 2013) provided a survey study about the increased emphasis placed on improving the quality of packaging and creating loyalty amongst customers. The results showed that packaging increases its key characteristic as the 'salesman on the shelf' at the point of sale (see., Silayoi et al., 2007), most consumers have the desire to feel confident with the product in terms of reliability and packaging before they purchase the product (see., Broadbridge \& Morgan, 2007), packaging has a great positive effect on the purchase of dairy products (Hysen \& Mensur, 2008), Ahasanul and Ali (2009) packaging plays an important role in influencing on the perception of consumers for the electronic products, however Gupta (2009) also show that effective packaging has a positive correlation with the buying behaviour in the food industry.

\subsubsection{Finished Goods Warehousing}

Baker (2007) reported that various prior studies (as in Frazelle, 2002; Kearney, 2004; Davis, 2005) stated that warehousing plays an important role to the success or failure in modern supply chains. The results found that the cost of warehousing represents $22 \%$ of the logistics costs and identified the key warehousing functions in serving the customer orders, in improving the return of inventory, in reducing the time to market, and in fulfilling the orders rapidly and efficiently. Whereas Chow, Choy, Lee and Lau (2006) recognized that planning and controlling the warehouse facilities are considered more complex process. The results found that most warehouses managers are suffering from a lack of both time and quality information which should be derived from monitoring and measuring the resources. They usually rely on their knowledge to formulate the material handling solutions in order to handle the different orders. The results found that warehousing process does no longer serve as a large-stock keeping; it has become a critical activity in the supply chain to outperform the competitors in customer service, in reducing the lead times and the costs (see, Koster, 1998). Whilst, Council of Supply Chain Management Professional Conferences CSCMP's (2013) reported that most companies find that 
the capabilities of the supply chains can push them toward the emphasis on fast delivery and improve efficiency. Besides, the location of warehouses is considered as a primary importance to be close to production facilities as well as to the customers, in order to reduce transportation costs, to reduce the lead times, and to save money of premium freight and the expediting fees. In addition, the managers of warehouses are responsible for getting rid of slow moving products and they are responsible for using the technical working in disposing of out-dated items or to store them out of the location.

Blomqvist (2010) concluded that, as suggested by several researches (see, e.g., Jiao et al., 2001; Oliva and Kallenberg, 2003; Johansson \& Olhager, 2004; Gu et al., 2007), the primary aim of the warehouses and distribution centers is to facilitate, control the movement of goods from suppliers to customers, and to meet the customers' demand in a timely and cost-effective manner. There is a set of factors required to control the systems of the warehouse such as transmit information, direct and schedule the work processes (e.g. job sequencing, job verification), monitor and report performance (e.g. picking rates, error rates) and increase performance accuracy through controlling the real-time for the operations, facilitating the communication throughout the supply chain to be associated with the improvement of customer service, and also promoting a set of added value which are derived from the market offerings. Measuring the accuracy of the warehouse functions depends on measuring the accuracy of the warehousing location and the accuracy of records, the percentage of items picked correctly, and the percentage of orders picked correctly. Measuring the percentage of the damage in the warehouse includes the percentage of items picked that are undamaged when received by the customer and the percentage of orders picked without damaging the merchandise, but the managers of the warehouse can depend on the number of orders that are fulfilled completely to measure the service level in the warehouse. Mekel et al. (2014) found that in order to avoid excess inventory in the warehouse, the production capacity should not exceed the economic order quantity EOQ.

\subsubsection{Inventory Control-Outbound}

Ann I et al (2014) indicated that, as suggested by various prior studies (see, e.g., Hanke et al., 2009; Jacobs et al., 2011), the inventory is one of the most expensive and important assets of many manufacturing companies. It represents a considerable percentage of the total invested capital and provides a significant link between production and sales of product, and constitutes a large percentage of the cost of production. The purpose of getting the right inventory in the right place at the right time and in the right quantity is controlling the inventory systems that are directly linked with the production function of any organization. This implies that the profitability of any organization is influenced directly and indirectly by the inventory management system. The control system of inventory may have a positive impact on the predictability of the future demands and the speed of the firm's production scheduling in order to meet customers' demand. If the goods arrived late or the operations are not completed at the right time; sales may be lost, production may be stopped, and the customers will be dissatisfied. Manufacturing companies seek to find ways to reduce the time needed to introduce the products and services to market place, to gain competitive edge, and to follow operating policies for maintaining and controlling the goods in the stock, and enhancing their operations to meet the projected orders.

The recent survey of Mogere et al. (2013) examined the effect of the decisions of inventory management on firm characteristics this measurement is based on the length of the cash conversion cycle, the size of the firm, the growth rate and the profitability. The results showed that the average inventories represented approximately $43.92 \%$ of the current assets and $18.17 \%$ of the total assets of the firm. This means that the decisions of inventory management should focus beyond the minimization of the relevant costs and the scheduling of material requirements that would have a high influence on the operational performance in the tea factories with a mean score of (4.02). In addition, if the inventory holdings increase significantly, this will lead to decreasing the firm's ability to generate internal resources, capital expenditure and the cash conversion cycle, whilst, the results showed that inventory holdings decreased significantly with the increase in profitability based on the marginal net profits. Finally, efficient forecasting of the inventory based on measuring the items required from the distribution centers, the flexibility of responding to the markets and on time delivery to have a positive influence on operational performance with mean scores of (4.02, 3.75 and 4.35 respectively).

According to Mathuva (2013) large firms and firms with longer cash conversion cycles tend to invest more in inventories, but firms with positive rate of sales and high net profit margins can hold fewer inventories than firms with negative sales rates and lower net profit margins. The study showed that the determinants of holding inventory are influenced by the firm's efficiency, performance and sustainability position when making inventory decisions. While Dimitrios (2008) investigated a possible linear relationship between inventory holdings and accounting performance in three types of Greek manufacturing firms belonging to the food, textile and chemicals sectors. The results confirm the existence of a robust linear relationship between them only in the chemicals 
sector. Also, holding too much of inventory consumes physical space, creates a financial burden, and increases the possibility of damage, spoilage and loss, inefficient management, poor forecasting, haphazard scheduling, inadequate attention to process and procedures, and poor stock returns. Finally, the results found that all the companies have a significant positive and direct relationship between reducing the inventory and improving their financial performance.

Ai-Chin, Abdul Hamid, Hon-Tat, Baharun, Yusoff and Rasli (2011) reported, as the reviews provided by (Sari, 2007; Thakkar et al., 2009), that the purpose of keeping and managing inventories of raw materials, work-in-process (WIP) and finished goods is to serve as a buffer between supply and demand processes and to improve the firm's capabilities through focusing on the time of materials delivery and shipment accuracy. An effective logistics network should be imperative in order to ensure a smooth flow of the materials between marketing and production, particularly for small manufacturing enterprises SMEs when they aim to improve their performance. The implementation of material flow management aims at reducing costs of non-value-adding efforts. In addition, supply chain managers should encourage the collaboration with inventory managers and should consider them as trading partners based on some indicators such as vendor managed inventory (VMI), efficient consumer response (ECR), collaborative planning, forecasting and replenishment (CPFR), minimizing demand uncertainty, reducing costs and improving profitability.

\subsubsection{Outbound Transportation}

As mentioned by (Rodrigues et al., 2008) many authors, (e.g., Childerhouse et al., 2003; Mason et al., 2003; Boughton, 2003; Christopher et al., 2004; Fowkes et al., 2004; Gomes et al., 2007), reported that there is an association between inventory management and transport, shipping and storage. They found that inaccurate forecasting and uncertainty of customers' orders can be caused by variations in customers' demands that will affect the transport freight, and also caused by variations in the frequency of making new orders. They concluded that poor information flow between the shipper and carrier about the schedule of shipping the orders, safety stock levels and the feedback about the transportation modes cause excessive holding inventories and, as a consequence, high levels of obsolescence. Besides, warehouse capacity can be an important constraint for optimizing the operations of the transport. Rodrigues et al. (2008) examined the relationship between the uncertainty in supply chain and the operations of transport. The results found that the inefficient scheduling of the operations of transport can make the arrival times of the orders become more difficult and unpredictable, and that the conflict existing between different market segments, lack of integration with the purchasing areas within supply chains, operations of transport not included in the total purchasing costs, lack of flexibility in the distribution network, in the distribution centre and in the store management have a negative impact on the efficiency of the performance and the effective planning of supply chain. Hans-Otto (2009) found that supporting the communication network between suppliers, production facilities and the sites of warehousing is a critical factor in the operational planning for the transportation problem in the consumer goods industry. The results showed that combining transportation orders with the purpose of efficient utilizing of load carriers, the distance, and the distinctive characteristics of some carrier freight rates; will lead to achieving cost savings of the transport operations.

The results of the (Meisel et al., 2011) study showed that in order to minimize the operating cost of a supply chain; the firm must minimize the cost of production facilities and the cost of transportation components. In addition, the results stated that putting constraints on the date of delivery requires the firm to work under the production strategy called make-to-stock and also to run a sufficiently large part of the supply chain. The combining of the location decisions and the decisions of production strategies seems to be the most promising approach to balance cost and service quality when designing a supply chain. Besides, Zailani et al. (2009) stated that tracking the shipping orders and coordinating the delivery times of the individual orders require timely conveying of information from their location.

\subsubsection{The Third Construct: Spanning Capabilities}

Spanning capability provides the horizontal connections to insure that the resources available across the supply chain are utilized efficiently to fulfill customers' needs (Day, 1994). Spanning capability consists of two components, the first is information dissemination capability which means competence and the second is strategy development which means capability. Hence, the spanning capability is focused on the development of the information dissemination capabilities within the supply chain as a crucial factor for collecting and transfering the different data in the supply chain to develop its strategy (Zhang, Vonderembse, \& Lim, 2006). Arshinder et al. (2008) found that Power (2005) stated that the information systems, the inventory management and the relationships within supply chain are three important elements that required to achieve the integration in the 
supply chain that aims at reducing the costs of purchasing and improving the level of customer service.

\subsubsection{Purchasing}

The purchasing strategy is a type of the strategies that attempt to provide the feedback related to the outcomes of the purchasing plans, and to provide information to the executive management about the effectiveness, efficiency and the contributions of the procurement function in order to enhance the overall firm' performance (Tracey et al., 2005). Hult, Ketchen JR, and Arrfelt (2007); Lawson et al. (2009) concluded that the top management should insert the procurement strategy within its strategic planning process as a vital part of the corporate strategy. Besides, supporting the strategic role for the efforts of purchasing managers aims at improving the purchasing activities, and increasing the need to information system. Purchasing performance is measured in terms of both of the contribution to the firm's success and the degree of success in formulating a competitive strategy.

According to Knight, Harland, Telgen, Thai, and Callender (2008); Paulraj, Chen, and Flynn (2007) purchasing and supply management (PSM) are crucial functions for the effective and efficient operations in the manufacturing companies now more than ever. They reported that the information system is one of the most important functions for planning, managing and supporting the linkage of the two activities of PSM. They found that the inability of the purchasing managers to use the information appropriately will be a key cause of failure to realise the objectives related to the selection of suppliers, the determination of the specification of items and the shipments schedule, and the measurement of the purchasing performance regularly. In addition, they stated that the procurement cycle includes all the necessary processes to ensure the materials are available for manufacturing products according to the production schedule, and to replenish both of the components of inventory and the stock-out levels in a distribution centers. Wahome (2013) examined the impact of procurement procedures, lead time of delivering materials, supplier selection process and e-procurement on inventory management to satisfy customers in terms of cost, quality and time of delivering the product or service in public sector. The results found that delaying the due date is a challenge which is caused by a certain factors relevant to suppliers such as the uncertainty of delivery times because the long time needed to complete the order cycle time, the managers of the procurement department often send to their suppliers short notices about the frequent changes of request schedules, or they don't send to them information about the time of the re-order point. Besides, the results found that the inaccuracy of demand forecast has a negative impact on both of the inventory levels in the warehouses and the safety stock level to meet the future demand regardless of the demand uncertainty which leads to confusion and inconsistency in the decisions taken by the purchasing managers.

The results of these studies (Kadima, Douglas, Kibet, \& Manase, 2013) found that procurement function has a positive influence on the efficiency of supply chain cycle time, supply lead time, level of delivering supplies with free defect rate, flexible purchase order cycle time, supplier's ability to respond to quality problems, initiatives of cost saving, low rejection rate from supplies and the accuracy of the documentation for delivering the supplies. In addition, the results disclosed that the strategic approach in practising the procurement activities has a positive impact on increasing the quality of both the specification and the technical aspects of the product items in terms of its fitness for use, its performance, and its safety and also, it has a positive impact on increasing the relative importance of the economic aspects of these items in terms of the price and the degree of the availability of these items. Whereas, the results revealed that the insurance on product development process has a minimal impact on ongoing business operations. Whereas the aim of this study (Noor, Saeed, \& Lodhi, 2013) is to discover whether there is an effective involvement of supply chain management in the development and expansion of the procurement plans in the textile industry in Pakistan. The results found that the involvement of supply chain management has a strong positive relationship with all of the following dimensions: with the procurement plans $(\mathrm{r}=.681)$, with the workers skills and quality control $(\mathrm{r}=.449)$, with the sourcing of purchasing, the overall outsourcing, government regulation regarding oversees shipping and low transportation costs $(\mathrm{r}=.529)$, and with the time delivery, order fulfillment, and quick contact with suppliers $(\mathrm{r}=.642)$.

\subsubsection{Customer Order Processing}

Muzumdar and Zinzuwadia (2013) reported that the council of supply chain provided a definition of the meaning of the fulfillment of the customers' orders as a percentage of meeting the received orders based on keeping complete and accurate documents with delivering them without damage. In addition, the complexity of managing these orders creates problems such as how keeping customers satisfied, adhering to delivery schedules, escalating supply chain costs, and keeping inventory higher than the company's needed. The primary factors that contributed in managing the expenditures of the customers' orders are the expediting orders' fulfillment and adding resources for responding to the delaying times of shipping.

Based on Stadtler (2005), the demand fulfillment needs to track the customer orders from the timing of the 
orders entry, the executing, till delivering them. Improving the competitiveness of the supply chain as a whole requires the integrating of both the organizational units along the supply chain, and the coordinating between the flow of materials, information and financial resources in order to fulfill the customers' demands. All the activities along the supply chain should consider the ultimate consumer as an integral part of the supply chain. Perry (2012) mentioned that some of the prior studies such as (Shapiro, Rangan, \& Sviokla, 1992; Lin \& Shaw, 1998; Croxton, 2003; Forslund, 2006; Forslund, 2007; Lambert, 2008), stated that once the company receives the customer order, the customer should identify the specification of all the items of the order that should be delivered quickly and accurately depending on exchanging the accurate information between them.

Arshinder et al. (2008) stated that there are some benefits accruing from the effective practices of supply chain customers (SCC) such as the elimination of the excess inventory, the reduction of the lead times, the improvement of customer service, the product development, the reduction of manufacturing costs, the increasing of flexibility to cope with demand uncertainty, the increasing of customer retention, and the enhancement of the revenue. The common problems related to the capabilities of the (SCC) are focused on how preparing the joint planning of order quantity, how preparing the joint activities of delivering and replenishment of the customers' orders through the coordination of the lead times. Sukati et al (2013) found that there are different approaches of the production systems to serve their customers orders. Where $60.48 \%$ of the sample applied production system called make to stock, $20.16 \%$ of the sample implemented another system called make to order. In addition, the firms' managers perceived the relative importance of the integration information technology dimension with mean score (4.83), the reliable delivery system dimension with mean score (4.00), and the information sharing of the customer order processing has the lowest mean score (3.74). Noor et al (2013) found that the time delivery exerts considerable impact on supply chain effectiveness with coefficient correlation $(\mathrm{r}=.642)$. There is a positive relationship between the order delivery, the order fulfillment, the quick supplier contact and the supplier responsiveness, and the three basic logistics activities: distribution, transportation, and the operations capabilities.

\subsubsection{Strategy Development}

According to Venus (2014) developing of the strategic supply chain management has generated much debate in many previous studies, it is not merely a function that supports business strategy but it is a key part of a business strategy. Some of these studies such as (Teece, Pisano, \& Shuen, 1997; Wisner, 2003; Shim izu \& Hitt, 2004), defined this developing as the ability to reconfigure the firm's resources, whereas Zahra, Sapienza and Davidsson (2006) reported that this developing leads to difference in the firms' ability to identify and to exploit the future growth opportunities required for attaining and sustaining the competitive advantage. In addition, Zhang et al. (2006); Upson, Ketchen, and Ireland (2007) stated that this developing contributes to achieving the strategic, operational, and technological integration of the supply chain activities through the information sharing to provide competitive advantage. According to Lockamy et al. (2004) some of the previous studies highlighted the need for the strategic planning of the supply chain to achieve a certain objectives. These objectives represented in facilitating the integration between the customers and the suppliers (Frohlich \& Westbrook, 2001; Hauguel \& Jackson, 2001); in designing the strategy of the supply chain (Fine, 2000), in aligning the relationship between the processes and the strategic objectives of the supply chain (Hicks et al., 2000; Tamas, 2000), in managing both of the order fulfillment and the safety level of inventory (Johnson \& Anderson, 2000; Viswanathan \& Piplani, 2001), and finaly, in adding value to the shareholders and achieving competitive advantage (Christopher \& Ryals, 1999; Ramsay, 2001). The literature review also resulted in the emergence of seven categories as a key for planning the decisions in the supply-chain management including operations strategy planning, demand management, production planning and scheduling, procurement, promise delivery, balancing change, and distribution management.

Sengupta et al. (2006) and Hult et al. (2007) stated that the use of a supply chain is not merely as a means to get products, but also is a tool to enhance the key business performance outcomes. The strategic value of supply chain management reflects how anf firm uses the supply chains as a competitive weapon to gain advantages over peers. The members of the supply chains should focus on how to create innovative solutions for understanding the customers' requirements, and how to match between their internal strategies and activities with the complexity that created by the rapid change in the environment. Which requires the need to developing their knowledge not only through gathering and disseminating the information about the market conditions, but also through tracking the effectiveness of the storage functions.

Green Jr et al. (2008) and Lawson et al. (2009) found that supply chain strategy should focus on the integration among all the processes and activities in order to present better services and products by creating value added for the final customer and improving the performance of the members of the supply chain. The results indicate that 
logistics performance has a positive impact on the supply chain strategy. Besides, the results found both logistics performance and supply chain strategy have a positive impact on the marketing performance, which in turn positively impact on the financial performance of the firm. The results disclosed that there is a set of intermediate factors in terms of supplier quality; flexibility, delivery, and cost performance have a positive impact on the implementation of supply chain strategy.

Rodrigues et al. (2008) found that number of previous researchers such as (e.g., Mason-Jones \& Towill, 1998; Boughton, 2003, Christopher \& Lee, 2004) argued that developing supply chain strategy is a hard work because of uncertainty which originated from four main sources including: the supply side, the manufacturing process, the control systems, and the demand side. The uncertainty regarded to inventory control systems can be classified as information uncertainty which composed of multiple dimensions such as time, speed, agility, flexibility, and quality. Meanwhile, the uncertainty of information may be due to the lack of visibility of information regarding to finished goods inventory, material inventory, work in process, actual demand and forecast, production plans, capacity and order status within the supply chain.

As mentioned in (Naude et al., 2011) prior studies about supply chain strategy (e.g., Wisner, Tan, \& Leong, 2009; Semchi-Levi et al., 2009; Monczka et al., 2010) consider supply chain integration to be as a strategic tool that aims to reduce costs and thus increase customer and shareholder value. Effective supply chain planning, built on shared information, trust among partners, increasing service levels, reducing the bullwhip effect, and better utilizing resources. The effective responding to changes in the market place, is a vital part of successful supply chain functioning. Developing Supply chain strategy will lead any businesses to act together to maximize total supply chain profits by determining optimal purchase quantities, product availabilities, service levels, lead times, production quantities and technical and product support at each level within the supply chain.

Manders (2009) examined the relationship between the flexibility of developing the supply chain strategy and customer satisfaction. The results found that the flexibility of developing supply chain strategy has a significant and strong positive impact on customer satisfaction with $(\beta=0.408)$. Based on (Sukati et al., 2013) the internal integration among all the functions is one of the most critical issues that faced any business. This may require achieving a comprehensive integrated planning and closed control systems in order to regulate the flow of goods and services from the suppliers to the customers. The internal integration is the first step for improving the business performance; it should be done before establishing any relation with the other external parties.

Based on (IshtiaqIshaq, Khaliq, Hussain, \& Waqas, 2012), the managers who are responsible for implementing the strategy of the supply chain found that this strategy can be developed in accordance to the modifications that may be done in the business strategy as a result of shifting the technology, the customers-suppliers demand, and the actions taken from the competitors. The highest value of the supply chains is focused on creating strategy that contributes to improve both of the competitive advantage and to enhance the organizational performance. Numerous well renowned firms including Toyota, Dell and Wal-Mart took their supply chain management as a key weapon to get and to attain a competitive advantage over others. Whitten, Green, and Zelbst (2012) reported that the success of the business performance depends on the abilities of supply chain partners, on building long-term strategic relationships, on taking accurate decisions with respect to all supply chain partners and on assigning the responsibility and the accountability system for all the supply chain managers. Noraini et al. (2014) reported that Datt (2009) found that there is a significant positive relationship between the firms that have a strategic supplier partnership and improving the competitive advantage to the firms in terms of the delivery time and the cost of both of the production and marketing.

\subsubsection{Information Dissemination}

Numerous studies such as (Fantazy, Kumar, \& Kumar, 2009; Elkhouly et al., 2012) emphasized on the importance of the information disseminating within the supply chain. Noraini et al. (2014) mentioned that according to (Sundram et al., 2011; Sezen, 2008) the information sharing is the essential dimension in managing the supply chain activities and in determining how the critical information is being shared among the supply chain members which derived from the customer, the product, and the market. The results revealed that the information sharing has a positive relationship with the supply chain performance. Cook et al. (2011) provided some previous studies that interpreted the information sharing dimension from different facets. Zhao et al. (2002) examined the impact of the information sharing and the coordination between the orders on the performance of the supply chain under the uncertainty condition of the demand. Lau et al. (2004) examined the impact of the information sharing on the inventory replenishments, while Singh et al. (2005) highlighted the important issues that link between the logistics functions and the information sharing, but Wang et al. (2008) studied the gap between the theoretical benefits of the mutual knowledge sharing among the supply chain partners and the 
practical complexity due to the various interaction processes between the companies, finaly, Shang et al. (2005) found that the information-based capability is the most critical impact on logistics performance that included the information sharing, the information technology, and the connection between all the parties in the supply chain.

Trkman et al. (2006) mentioned that many companies are pursuing to support the interactive relationships and the collaboration with the suppliers in terms of developing the products, integrating the key business process and cross-functional information sharing. Elkhouly et al. (2012) found that, there is no significant difference among the Egyptian manufacturing firms regarding to the information sharing that is exchanged between all the parties of the supply chain. The results found that the public sector in the sample differs from the private sector in using the information technology which returns to the culture of the organization and the top management support.

Prajogo et al. (2012) examined the impact of the flow of both of the information and the materials between the partners of the supply chain on the operational performance of the firm. The results found that the intensive flow of the information between the firms and their suppliers has a significant and positive impact on the level of the logistics performance $(r=0.39)$. In addition, the results revealed that the information sharing helps the firms in developing the strategy of the supply chain regarding to the flow of the materials, and the products and improving the strategic decision in their operations. Recording the historical data of the point of sale helps the suppliers to successfully forecast the demand which subsequently improves the service level to their customers. The results revealed that there is a positive impact of the real-level of the inventory on the capabilities of the suppliers to plan for scheduling the delivery time, improving the service levels and reducing the inventory costs. Based on (Giovanni, 2009) many of the previous researches stated that there is more than $70 \%$ of the supply chain managers responsible for the flow of the knowledge across the chain chain for exploiting the actual resources for disseminating the knowledge, and for creating the new opportunities for improving, and developing new channels of communication. In addition, almost $80 \%$ of the supply chain managers agreed to incorporate the financial results of the supply chain within the framework of the knowledge management in order to optimize the firm's performance. Whilst, Shang et al. (2005); Rodrigues et al. (2008); Fantazy et al. (2009); Elkhouly et al., (2012); Prajogo et al. (2012); Noraini et al. (2014) confirmed that the information-based capability-which consists of both of the information sharing and the information technology- has the most critical impact on improving the logistics performance.

\subsubsection{Performance}

Prior researches suggested that there is a direct link between the SCM practices and the organizational performance, some studies emphasized on operational measures, while others stressed on financial measures (Cook et al., 2011). Numerous studies have been used different indicators to measure the firm performance such as the growth of sales, the growth of market share and the profitability (see., Narasimhan \& Kim, 2002; Narasimhan et al., 2008); perceived value, customer loyalty, market performance and financial performance (see., Tracey et al., 2005); product quality, customer service, competitive position, market share, average of selling price and return on assets (see., Tan et al, 2002); the operational performance is measured by the performance of lead-time and the financial performance is assessed through the return on investments and the return on sales (Jin, 2006). Whilst Fantazy et al. (2009) stated that performance has been defined in a variety of ways in the literature such as sales growth rate (e.g., Fawcett et al., 1997; Tracy et al., 2005), return on investment (e.g., Lynch et al. 2000; Tracy et al. 2005; Kim, 2006), market share (e.g., Fawcett et al., 1997; Daugherty et al., 1998; Tan et al., 1999; Stank, et al., 2003; Tracy et al., 2005), customer loyalty (e.g., et al., 2006; Sanchez et al., 2005).

Whereas Perry (2012) found that based on the previous studies (e.g., Vickery, Calantone, and Droge, 1999; Stock, Greis and Kasarda, 2000; Li, Ragu-Nathanb, Ragu-Nathanb, and Rao, 2006) organizational performance can be measured based on financial and market indicators such as market share, return on investment, profit margin on sales, overall of competitive position and the growth of market share, and return on investment. In addition, the results found that strategic development for fulfilling the customer order processing is a significant and positive relationship with the organizational performance $(\mathrm{r}=0.93)$.

Whilst Kelly et al (2013) mentioned that the profitability of the firms are measured based the return on equity (ROE), the return on assets (ROA), the net income and the return on sales, regardless of the types of service or products they offer. They disclosed that the managers of many firms are considered the return on investment as a very important variable for measuring the profitability. Tracey et al (2005), mentioned that the purchasing activities, the supply management, and the customer responsiveness have a profound impact on a firm's financial performance (see., Stalk \& Hout, 1990; Jayaram et al., 1999; Stank et al., 1999; Carr \& Pearson, 1999; Zsidisin \& Ellram, 2001; Injazz, Antony, \& Augustine, 2004). 
Van Weele and van Raaij (2014) found that the mean score for the financial measures is (3.6601) and the mean score for the non-financial measures in terms of customer satisfaction and cycle time is (3.6449), this result revealed that these two measures are equally important and there are no significant differences between them in identifying the performance of the procurement function. This means that the financial and non-financial measures are not clearly differentiated in a daily practice related to the time taken to complete procurement procedures, the flow of information among the parties, the level of competition, and the durability of what is purchased. Kamel, Vinod, and Uma (2010) tested the impact of the strategic purchase on both of the SCM practices and the hotel's performance. The results indicated that the strategic purchase has a positive relationship with the supplier, the financial performance and the customer satisfaction

Fantazy et al. (2009) found that the linkage between customer satisfaction and a firm's financial performance is based on customer loyalty and the possibility of the retention of customers. This result is in agreement with (e.g., Kaplan \& Norton, 1992; Sanchez \& Perez, 2005), who found that there is a positive relationship between improving the customer time responsiveness and increasing both of the market performance and the firm's financial performance.

Knight et al. (2008) stated that the importance of purchasing and supply management (PSM) to senior management is how to demonstrate the link between the purchasing practices and the financial performance measures in terms of the return on assets, and the ratio of the market value of the firm to the replacement cost of its assets. Green $\mathrm{Jr}$ et al. (2008) found that the integration between production department, purchasing department, marketing department, and management information system have a positive relationship with the supply chain performance. In addition, supply chain managers should consider how to integrate between the supply chain strategies with the firm strategy. This integration could carry out each member in the supply chain to maximize the value of his duties, to improve the firm performance in practicing the supply chain activities, to integrate the processes, and to reduce the lead time. Finally, the results revealed that the supply chain strategy and the logistics performance has no a direct impact on the financial performance of the firm.

According to the results of this study (Bavarsad, Azizi \& Alesa, 2013) the supply chain strategy has a significant and positive relationship with the financial performance $(\mathrm{r}=0.489)$ and with the marketing performance $(\mathrm{r}=$ 0.445). Li et al. (2006) found that there is a direct effect of the SCM practice on the organizational performance in terms of market share, return on investment, growth of market share, growth of sales, growth in return on investment, profit margin on sales and overall competitive position with standardized coefficient $(\beta=0.24$, $\mathrm{P}<0.05$ ) and there is an indirect effect of the SCM practice on the organizational performance with standardized coefficient $(\beta=0.26, \mathrm{P}<0.01)$. In addition, the results showed that the SCM practices has a direct effect on the operational performance and has an indirectly affect financial performance when improving operational performance. Florian and Constangioara (2013) analyzed the impact of different facets of performance on the financial and the non-financial measures within Romanian supply chains. The result showed that from the customers' perspective, there is a significant relationship between supply chains and both of the time delivery and market share, whereas there is an insignificant relationship between supply chains and the rate of damages in shipments that transporting to the customers.

Mekel et al. (2014) found that many mistakes happen during the distribution processes of the products that can effect on the flow of the supply chain, whereby it does not run smoothly. The uncertainty of the lead time is one of these mistakes that cause the stock out, increase the cycle time of processing and reduce the efficiency of a product line. Kumar et al. (2014) tested the direct and indirect relationships between supply chain practices and supply chain performance. The results show that supply chain practices that measured by five indicators named closing partnership with suppliers, closing partnership with customers, strategic planning, e-procurement, and holding safety stock have a positive causal relationship with supply chain performance that measured by three indicators named the improvement in the lead time, inventory turn, and product development cycle with $(\beta=0.079)$. In addition, the results showed that the five indicators of the supply chain practices explain $34 \%$ of the variance in the supply chain performance. This result is in agreement with the results of these studies (e.g., Ou et al., 2010; Huo, 2012; Deshpande, 2012), which revealed that supply chain practices have a positive effect on the firm performance, while supply chain practices have an indirect impact on the financial performance and the value added to the customer.

Ramanathan (2014) found that supply chain partners can extend their partnership further in order to increase the profit, to reduce the lead time and to improve the customers' satisfaction. This research suggested that the poor forecast accuracy of demand, the top management will do efforts for increasing the accessibility of information related to the product, the customer demand, the transaction, and inventory in order to improve both of the efficiency of information sharing and the profit proportion. In addition, the lead time and the capacity utilisation 
contribute to improving the collaboration within the supply chains in terms of on-time delivery of raw materials, and timely planned production which help to sustain the competitive edge, to increase the sales and the revenues, and the business performance.

As mentioned in (Noraini et al., 2014) Sundaram et al. (2011) demonstrated that how to manage the customer complaints, to enhance customer satisfaction and to create long term relationship with customer; whilst, Chow et al. (2008) found that supply chain practices that made up of customer relationship have a direct impact on the organizational performance in Taiwan and have indirect impact on organizational performance in US. Hence, customer relationship will be able to enhance the supply chain to achieve better performance. According to Azad and Mohammadi (2013) the packaging process plays an important role on developing the product and gaining the bigger market share. The most important factor in promoting the product is the availability of data that related to the production systems, the specifications of the product and the brand name of a product. The results indicated that the brand loyalty, physical characteristics, pricing effects, performance characteristics, brand relationship and brand position are major factors that influenced on improving the packing of food industry. In addition, Giahi (2012) stated that the color and the type of the packing process are important factors that have a positive impact on the buying rates.

However, Azad et al (2013) revealed that the product which has a good label and precise information on a product could significantly impact on customer's confidence in this product, while the other visible information did not have much impact on the customer's confidence. Flynn, Huo, and Zhao (2010) examined the influence of integrating the relationship between the customers and the suppliers on business performance. The results found that the financial performance is the main source of evaluating the supply chain performance. The results found that the indicators used to measure the business performance revealed that the factor loading $(0.75)$ for the growth in sales, (0.88) for the return on sales, $(0.85)$ for the growth in profit, $(0.78)$ for the growth in market share, $(0.88)$ for the return on investment. Whereas, the internal integration of the supply chain activities are positively related to business performance, although the relation between the suppliers and the customers are not directly related to business performance but through the operational performance. This study reported that, Droge et al. (2004) found that the internal and external integration of supply chain are only related with the financial performance and the market share of the firm, whereas, Williams et al. (2002) and Wisner (2003) found that the greater the customer loyalty and the willingness to pay a premium price for a high product quality are two indicators that reflect the superior suppliers responsiveness to achieve the customers' requirements. In addition, the firms that follow the market-oriented approach can serve their customers better than others, can result in satisfying their customers, and can lead further to improvement both of the financial performance and the market share.

Venus (2014) found that there is a significant correlation between the supply chain management in the companies which have a high maturity in the practices, processes and strategies and achieving low level of volatility in their financial performance. Zhang, Dixit, and Friedmann (2010) pointed out that some of the previous studies such as (e.g., Fornell et al., 1996; Agustin \& Singh, 2005; Reinartz \& Kumar, 2000; 2002; 2003) stated that customer loyalty is a critical factor for a firm's long-term profitability and proved that there is a positive relationship between customer loyalty, customer revenue, and customer retention in the area of consumer packaged goods. However, customer loyalty may not have a positive impact on customer profitability. Similarly, Gupta and Lehmann (2005) stated that many firms spend enormous amounts of money to foster customer loyalty; however they achieve little tangible results. In addition, the increased customer lifetime value for maintaining a loyal customer is the joint result of increased yearly gross margin (\$5.03 versus \$1.65) and increased yearly retention rate (92 percent versus 68 percent). Lwiki et al. (2013) disclosed that there is a significant positive relationship between inventory management practices and financial performance in sugar manufacturing firms in Kenya. This study noted that prior studies have already addressed several aspects of the relationship between inventory management practices and financial performance such as (Agus \& Noor, 2006) which examined the relationship between inventory management practices and financial performance and measured the impact of manager's perceptions of inventory on supply chain management practices. The results revealed that inventory management practices have a significant positive relationship with the rate of profitability and the rate of return on sales.

Augustine et al. (2013) proved that there is a significant positive relationship between the good inventory management and both of the organizational effectiveness with $(\mathrm{r}=.898)$ and the organizational profitability with $(\mathrm{r}=.843)$. The results concluded that the inventory management is a vital variable to the success and the growth of organizations which directly effect on the quality of products. The results revealed that in most organizations, the direct materials represent up to $50 \%$ of the total product cost may be due to the money which entrusting in 
the inventory, thereby affecting the profitability of the organization, or they do not have a good system to control the holding inventory. Therefore, this creates conflict between the inventory management, the production processes, the profitability and the effectiveness of the organizations.

Ai-Chin et al. (2011) proposed a model that presents a framework for SCM practices and its impact on the organizational performance and the profitability through presenting the results of number of prior studies. Deloitte's study (2003) that indicated to nearly 600 companies in 22 countries around the world supported that the marginal profit represents up to $73 \%$ in the companies which excel in the SCM practices, while, Edgell's study (2003) revealed the marginal profit is increased more than $40 \%$ comparing with others as a result of employing the advanced practices in the SCM. Whereas, Lee and Whang (2009) found that exchanging the information between all the parties of the supply chain has a positive impact on the rate of the profitability in the consumption goods industry and also on the reduction of the expenses in the computer manufacturing industries. Tutuncu et al (2008) found that the integrative inventory management, the level of strategic partnership with suppliers, data integration through departments within the hospital, periodic interdepartmental meetings among internal function, and stable procurement through network have positive relationships with the external customer with factor loadings $(\mathrm{r}=0.754, \mathrm{r}=0.846, \mathrm{r}=0.830, \mathrm{r}=0.737, \mathrm{r}=0.704)$ respectively. In addition, the results found that the staff hospital perceptions have a positive relationship with integrating all the dimensions of SC with ( $\mathrm{r}=$ 0.292).

Sukati, Abdul Hamid, Baharun, Tat, and Said (2011) stated that businesses today operate in a complex and turbulent marketplace (e.g., Christopher, 2000; Goldman et al., 1995), this requires from them developing the supply chain management practices for improving the profitability, the quick response to customers' orders, the ability to deliver value to customers, and the interconnection and interdependence among the businesses. In addition, the expansion of the markets from domestic to global markets requires from the supply chain management formulating goals that allow them to deal with the increasing of the demand rates, the need to facilitate the time of delivery and to provide products and services with high quality and the increasing of demand on the variety of items. Tracey et al. (2004) and Lawson et al. (2009) mentioned that customer value can be created and firm performance enhanced by optimizing the inbound and the outbound of the logistics functions.

\subsection{Conceptual Framework}

A company's supply chain divides an organization into a sequence of primary activities, inbound logistics, operations, outbound logistics, marketing and sales, and service; along with supporting such activities. SCM involves the integration of these business processes and provides products, services and information that add value for customers (Chen, Leu, \& Chiou, 2006). Based on Day (1994) who developed the conceptual dimensions and measurement scales for three SCM capabilities: outside-in (physical supply), inside-out (physical distribution) and spanning processes capabilities, and based on Tracey et al. (2004) and Tracey et al (2005) who empirically tested this model; the current study will investigate the impact of a firm's SCM capabilities on perceived product value, customer loyalty, market performance and financial performance to support the theoretical concepts and to collect data in another environment to confirm, refine and expand the presented model that may enhance the generalization and usefulness of the findings.

Figure 1 displays the proposed relationships between the constructs of this research and considers supply chain management capabilities as a function of the three constructs delineated earlier: outside-in capabilities (OIC), inside-out capabilities (IOC) and spanning capabilities (SC), and examine the effect of these three constructs on the business performance construct that includes four indicators which are the perceived product value, customer loyalty, market performance and financial performance. Each of these constructs includes four of the 12 distinct SCM/logistics processes (e.g., Ernst \& Whinney, 1987; Johnson \& Wood, 1993; Novack et al., 1994; Coyle et al., 1996; Stock \& Lambert, 2001). 


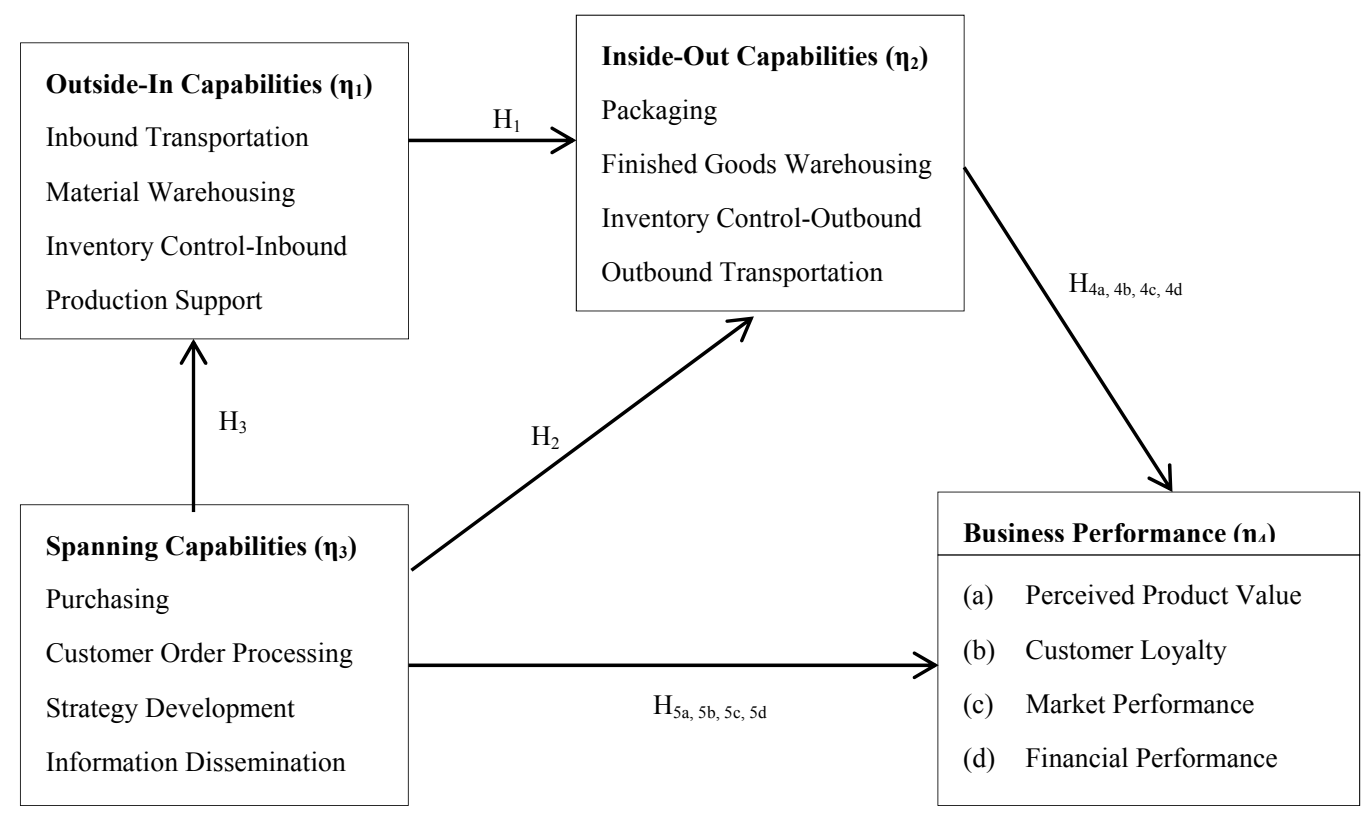

Figure 1. Conceptual model

Source: Tracey et al. (2005).

\subsection{Hypotheses}

According to the results of the empirical study provided by (Tracey et al., 2005) that are concerned with testing the proposed model presented by Day (1994) in which a company's capacity to exploit external possibilities depends on the ability of its outside-in capabilities to serve its inside-out capabilities. This study examines the supply chain management capabilities that consist of outside-in capabilities, inside-out capabilities and Spanning capabilities and its relationship to business performance. The arrows in figure 1 point out the relationships between the three constructs of supply chain management capabilities and business performance; and match the described hypotheses $\mathrm{H} 1$ till $\mathrm{H} 5$. Therefore, the following hypotheses will be tested:

$\mathrm{H}_{1}$. Outside-in capabilities are positively related to inside-out capabilities.

$\mathrm{H}_{2}$. Spanning capabilities are positively related to inside-out capabilities.

$\mathrm{H}_{3}$. Spanning capabilities are positively related to outside-in capabilities.

$\mathrm{H}_{4}$. Inside-out capabilities are positively related to business performance a) performance product value, b) customer loyalty, c) market performance, d) financial performance.

$\mathrm{H}_{5}$. Spanning capabilities are positively related to business performance a) performance product value, b) customer loyalty, c) market performance, d) financial performance.

\section{Methodology}

\subsection{Measures}

\subsubsection{Background Variables}

The research is conducted based on the perspective of managers in a sample of companies in the Egyptian industrial sector. Data are gathered by using a questionnaire survey which is employed to 250 respondents.

As mentioned by (Tracey et al., 2005), the measures used to test the relationships among outside-in process capabilities (OIC), inside-out process capabilities (IOC), spanning process capabilities (SC) and business performance (P) are derived from Day (1994) who classified the framework to categorize 12 distinct $\mathrm{SCM} /$ logistics processes by placing them into these three constructs of capabilities. Each of these constructs includes four of the 12 distinct SCM/logistics processes.

The first construct OIC consists of four dimensions and 20 items, inbound transportation (four items); material warehousing (four items); inventory control-inbound (seven items); and production support (five items). The second construct IOC consists of four dimensions and 21items, packaging (seven items); finished goods 
warehousing (four items); inventory control-outbound (five items); and outbound transportation (five items). The third construct SC consists of four dimensions and 22 items, purchasing (six items); customer order processing (six items); strategy development (five items); and information dissemination (five items). Four dimensions and 8 items are used to test the business performance BP, perceived product value (two items), customer loyalty (two items); market performance (three items); and financial performance (one item). The respondents are asked to indicate a five-point Likert scale ( $1=$ unacceptable, 5 superior) which is employed for the OIC and IOC items, a five-point Likert scale measured scale items for SC construct ranging from 1 (strongly disagree) to 5 (strongly) and a five-point Likert scale measured scale items for the BP with possible responses ranging from 1 (unacceptable) to 5 (superior).

\subsection{Sampling}

\subsubsection{Sample Size}

The sample came from the manufacturing companies that are active in three different industrial sectors (furniture and wood, engineering, and weaving and textile). To increase the chances that a company can have separate functions for product manufacturing, logistics and spanning, as required by the current research; the respondents came from nine positions (sales, information system, planning, marketing, manufacturing, engineering, finance, distribution, and purchasing) whose functions are directly related to SCM processes from 30 different companies.

The respondents include presidents/CEOs, general manufacturing managers, production managers, logistics managers, purchasing managers and marketing managers. The number of complete and usable responses is 224 out of 250 responses, with a response rate of $89.6 \%$. Of these responses, 26 questionnaires are rejected because there are many unanswered questions during filling the questionnaire, and also because some respondents are unable to answer all questions because the questions are not applicable to their company. Lwiki et al. (2013) concluded that Ying (2006) suggested that organizations need to have more than 100 employees to be effectively involved in the supply chain activities. It is found that all the companies in the current research have more than 500 employees.

\subsection{Data Analyses Instruments}

This research develops a reliable instrument to measure the three types of constructs of SCM capabilities (OIC, IOC and SC) and BP indicators (perceived customer value, customer loyalty, market performance, and financial performance) from the point of view of the managers. The cross sectional data is analyzed using SPSS 17.0 for windows.

1) The reliability analysis results for each construct will be reported first.

2) Then, the results of the hypotheses will be described by using descriptive statistics.

3) Because the research model has a set of predictors (individual dimensions of OIC; individual dimensions of IOC; and individual dimensions of SC), data analysis at the dimension level is used for determining the effect of specific dimensions of OIC, IOC, SC on BP. Because of the lack of a well-defined predictive model of SCM capabilities, a stepwise regression analysis will be performed, First, to determine which of the dimensions of OIC construct (i.e. inbound transportation, material warehousing, inventory control-inbound and production support and SC construct (i.e. purchasing, customer order processing, strategy development, and information dissemination are significant predictors of IOC construct. This regression is carried out independently for the OIC dimensions on IOC, followed by the SC dimensions on IOC. Second, to determine what dimensions of SC construct (i.e. purchasing, customer order processing, strategy development and information dissemination are significant predictors of OIC construct. Third, to determine what dimensions of IOC construct (i.e. Packing, finished goods warehousing, inventory control-outbound, and outbound transportation and SC construct (i.e. purchasing, customer order processing, strategy development and information dissemination construct are significant predictors of BP dimensions (i.e. Perceived product value, customer loyalty, market performance and financial performance, and these regressions are carried out independently for the IOC construct on BP dimensions, followed by the SC construct on BP dimensions.

\section{Results}

\subsection{Reliability Test}

The reliability analysis is used to determine if the internal coherence between the individual items is high enough to measure the three constructs of SCM capabilities (OIC, IOC, \& SC) and BP. An overview of reliability analysis for each item of the three constructs of SCM capabilities and business performance are shown in Table 
1.

Table 1. Reliability analysis for each item of the three constructs of SCM capabilities and business performance construct

\begin{tabular}{|c|c|c|c|c|c|}
\hline Construct Dimension & $\begin{array}{l}\text { Scale Mean if } \\
\text { Item Deleted }\end{array}$ & $\begin{array}{l}\text { Scale Variance if } \\
\text { Item Deleted }\end{array}$ & $\begin{array}{l}\text { Corrected Item-Total } \\
\text { Correlation }\end{array}$ & $\begin{array}{l}\text { Squared Multiple } \\
\text { Correlation }\end{array}$ & $\begin{array}{l}\text { Cronbach's Alpha if } \\
\text { Item Deleted }\end{array}$ \\
\hline \multicolumn{6}{|l|}{ OIC } \\
\hline Inbound transportation & 50.3334 & 17.470 & .321 & .163 & .803 \\
\hline Material warehousing & 50.5023 & 17.074 & .297 & .116 & .810 \\
\hline $\begin{array}{l}\text { Inventory } \\
\text { control-inbound }\end{array}$ & 50.2711 & 17.830 & .306 & .151 & .803 \\
\hline $\begin{array}{l}\text { Production support } \\
\text { IOC }\end{array}$ & 50.2667 & 17.426 & .332 & .208 & .802 \\
\hline Packaging & 50.2109 & 17.501 & .531 & .403 & .790 \\
\hline $\begin{array}{l}\text { Finished goods } \\
\text { warehousing }\end{array}$ & 50.3389 & 17.109 & .487 & .329 & .790 \\
\hline $\begin{array}{l}\text { Inventory } \\
\text { control-outbound }\end{array}$ & 50.5156 & 17.482 & .370 & .249 & .799 \\
\hline $\begin{array}{l}\text { Outbound } \\
\text { transportation } \\
\text { SC }\end{array}$ & 50.3396 & 17.542 & .444 & .394 & .794 \\
\hline Purchasing & 50.4947 & 17.970 & .366 & .222 & .799 \\
\hline $\begin{array}{l}\text { Customer } \quad \text { order } \\
\text { processing }\end{array}$ & 50.5060 & 17.898 & .434 & .251 & .795 \\
\hline Strategy development & 50.3183 & 17.781 & .374 & .290 & .798 \\
\hline $\begin{array}{l}\text { Information } \\
\text { dissemination }\end{array}$ & 50.4000 & 17.949 & .355 & .201 & .799 \\
\hline $\mathrm{BP}$ & & & & & \\
\hline $\begin{array}{l}\text { Perceived product } \\
\text { value }\end{array}$ & 50.1189 & 17.239 & .514 & .376 & .789 \\
\hline Customer loyalty & 50.2189 & 16.743 & .556 & .531 & .785 \\
\hline Market performance & 50.2853 & 16.956 & .540 & .543 & .787 \\
\hline Financial performance & 50.2134 & 17.446 & .481 & .370 & .792 \\
\hline
\end{tabular}

Cronbach's alpha among 16 items in the questionnaires exceeded 0.7. A commonly used value for acceptable reliability is 0.7 based on (Hair, Anderson, Tatham, and Black, 1998). The Cronbach's alpha scores for all constructs (OIC, IOC, SC, and BP) can be considered as internally consistent which are considered acceptable and sufficient for basic research. Only the Cronbach's alpha scores for the OIC construct are higher than 0.8 . The findings showed that material warehousing dimension, as one of the OIC construct, has the highest value of alpha coefficient $(\alpha=.810)$ and that customer loyalty dimension, as one of the construct of BP, has the lowest value of alpha coefficient $(\alpha=.785)$.

\subsection{Statistics and Data Analysis}

Table 2. The descriptive statistics for the three constructs of SCM capabilities and the construct of business performance on a factor level

\begin{tabular}{lllllll}
\hline Construct Dimension & $\mathrm{N}$ & Minimum & Maximum & Mean & \multicolumn{2}{c}{ Std. Deviation } \\
& Statistic & Statistic & Statistic & Statistic & Std. Error & Statistic \\
\hline OIC Inbound transportation & 224 & 3.00 & 4.90 & 3.8321 & .03062 & .45825 \\
Material warehousing & 224 & 2.80 & 5.00 & 3.9009 & .03357 & .50237 \\
Inventory control-inbound & 224 & 2.90 & 5.00 & 3.8152 & .03367 & .50392 \\
Production support & 224 & 2.40 & 5.00 & 3.7201 & .03276 & .49026 \\
\hline
\end{tabular}




\begin{tabular}{lllllll}
\hline IOC Packaging & 224 & 2.70 & 5.00 & 3.7558 & .03221 & .48202 \\
Finished goods warehousing & 224 & 2.30 & 5.00 & 3.7576 & .03596 & .53825 \\
Inventory control outbound & 224 & 3.00 & 5.00 & 3.8812 & .03503 & .52422 \\
Outbound transportation & 224 & 3.00 & 5.00 & 3.8223 & .03191 & .47761 \\
SC Purchasing & 224 & 3.00 & 4.90 & 3.9634 & .02703 & .40457 \\
Customer order processing & 224 & 3.10 & 5.00 & 3.9701 & .02683 & .40162 \\
Strategy development & 224 & 3.00 & 5.00 & 3.9304 & .02853 & .42697 \\
Information dissemination & 224 & 3.20 & 5.00 & 3.9705 & .02595 & .38831 \\
BP Perceived product value & 224 & 3.00 & 5.00 & 3.9714 & .02985 & .44680 \\
Customer loyalty & 224 & 2.00 & 5.00 & 3.4643 & .05463 & .81767 \\
Market performance & 224 & 2.70 & 5.00 & 3.9714 & .02877 & .43065 \\
Financial performance & 224 & 3.00 & 5.00 & 4.0598 & .02905 & .43480 \\
Valid N (list-wise) & 224 & & & & & \\
\hline
\end{tabular}

From the above table, the first of SCM capabilities is the (OIC) construct that have been adapted to a great extent (mean lies between 3.8171 and 5). The highest factor is material warehousing (mean, 3.9009), followed by inbound transportation (mean, 3.8321), inbound inventory control (mean, 3.8152), and the least factor is production support (mean, 3.7201). The second of SCM capabilities is the (IOC) construct that have been adapted to a great extent (mean lies between 3.8040 and 5). The highest factor is inventory control outbound (mean, 3.8812), followed by outbound transportation (mean, 3.8223), finished goods warehousing (mean, 3.7576), and the least factor is packing (mean, 3.7558). The third of supply-chain management SCM capabilities is the (SC) construct that have been adapted to a great extent (mean lies between 3.9586 and 5). The highest factor is information dissemination (mean, 3.9705), followed by customer order processing (mean, 3.9701), purchasing (mean, 3.9634), and the least factor is strategy development (mean, 3.9304). The construct of BP has a great extent (mean lies between 3.8668 and 5). The highest indicator is financial performance (mean, 4.0598), followed by the two indicators perceived product value and market performance that has the same mean score $(3.9714,3.9714)$ respectively, and the least indicator is customer loyalty (mean, 3.4643). These findings indicated that while the three constructs of SCM capabilities have been adopted and implemented to a great extent, the majority of the factors underlying these three constructs have been implemented to a moderate extent. These findings implied that SCM capabilities still have lots of ground to cover, in terms of fully implementing supply chain best practices.

\subsection{Stepwise Regression Analysis}

A stepwise regression analysis is performed to determine what dimensions of supply chain management capabilities (i.e. outside-in capabilities (OIC), inside-out capabilities (IOC), and spanning capabilities (SC) are significant predictors of business performance (i.e. perceived customer value, customer loyalty, market performance, and financial performance).

\subsubsection{Findings about the (OIC Dimension Level) and the (IOC) Construct}

The table below (Table 3 ) shows the model summary of the stepwise regression results for the (OIC) dimensions (inbound transportation, material warehousing, inventory control-inbound and production support) on all the dimensions of the (IOC) construct (packing, finished goods warehousing, inventory control-outbound and outbound transportation).

$\mathrm{W}$

Table 3. Dimension level stepwise regression results model summary for (OIC) dimensions on IOC

\begin{tabular}{lcccccccc}
\hline Step & $\mathrm{R}$ & $\mathrm{R}^{2}$ & $\mathrm{R}_{\text {adj }}^{2}$ & $\Delta \mathrm{R}_{2}$ & $\mathrm{~F}_{\text {chg }}$ & Sig $\mathrm{F}_{\text {change }}$ & $d f_{1}$ & $d f_{2}$ \\
\hline 1-inbound transportation & 0.381 & 0.145 & 0.136 & 0.145 & 14.102 & 0.000 & 1 & 222 \\
2-material warehousing & 0.621 & 0.386 & 0.383 & 0.386 & 79.563 & 0.000 & 2 & 221 \\
3-inventory control-inbound & 0.675 & 0.456 & 0.453 & 0.456 & 86.037 & 0.000 & 3 & 220 \\
\hline
\end{tabular}


Table 4. Coefficients for (OIC) dimensions on the construct (IOC)

\begin{tabular}{llll}
\hline $\mathrm{B}$ & $\beta$ & $\mathrm{T}$ & Sign \\
\hline 0.372 & 0.381 & 4.136 & 0.000 \\
0.398 & 0.621 & 11.814 & 0.000 \\
0.483 & 0.675 & 13.640 & 0.000 \\
\hline
\end{tabular}

The stepwise regression results shown in the above table indicated that three dimensions only out of four of the overall model of the (OIC) construct (namely inbound transportation, material warehousing, and inventory control-inbound) that reasonably predict the (IOC) construct. A summary of the regression coefficients is presented in Table 4 which indicated that only three dimensions of (OIC) have a strong positive relationship with all the dimensions of the (IOC) at the significance level $5 \%$ which statistically predicts the (IOC) construct in the following order:

- Inventory control-inbound has a strong significant positive correlation with all the dimensions of the (IOC) with the standardized regression coefficient $(\beta=0.675 ; \mathrm{p}=.000<.05)$ and explains $45.3 \%$ ( $\mathrm{R}^{2}$ adj) of the variance in $(\mathrm{IOC})$ construct $(\mathrm{F}=86.037, \mathrm{p}<0.000)$. Which indicates the great awareness among the managers of these companies towards the importance of practicing the activities which emphasize on the accuracy of records concerning the quantities and the locations of materials in the warehouse, the length of time required to update inventory records and limiting the number of production delays due to materials being out of stock at the warehouse. Accordingly, the greater the overall quality of inventory control regarding incoming materials, the greater the improvement in all the dimensions of the (IOC) construct will occur.

- Material warehousing has a strong significant positive correlation with all the dimensions of the (IOC) construct with $(\beta=0.621 ; \mathrm{p}=.000<.05)$, and explains $38.3 \%\left(\mathrm{R}^{2}\right.$ adj) of the variance in the (IOC) construct $(\mathrm{F}=79.563, \mathrm{p}<0.000)$. This means that the greater concern of the respondents on the main role of the overall quality of material warehousing, storing materials intact at the warehouse, picking components accurately and responding promptly to special requests, the greater the improvement in all the dimensions of the (IOC) construct will occur.

- Inbound transportation IT has a significant positive correlation with all the dimensions of the (IOC) construct with $(\beta=0.381 ; \mathrm{p}=.000<.05)$, and explains $13.6 \%\left(\mathrm{R}^{2} \mathrm{adj}\right)$ of the variance in the (IOC) construct $(\mathrm{F}=14.102, \mathrm{p}<0.000)$. This means that the greater the respondents get interested in delivering shipments on time, with a timely reply to inquiries, with the overall quality of inbound transportation and with reacting quickly to special requests, the greater the improvement in all the dimensions of the (IOC) construct. Since that $\left(\mathrm{R}^{2}\right.$ adj) must be at least 0.10 (i.e. the given independent variables must explain at least $10 \%$ of the variance in dependent variables); therefore, it is clear that product support does not significantly contribute to the prediction of the dimensions of the (IOC) construct. This finding may indicate that the respondents do not have enough attention to the importance of the extent of delivering the materials to smooth handling by manufacturing/assembly, or to the transfer of materials for meeting production schedule, or to moving the materials to the correct production location, or to responding expediently to special requests, which are needed for improvement the dimensions of the (IOC) construct.

This model is sufficient to support and partially accept hypothesis $\left(\mathrm{H}_{1}\right)$ which states that outside-in capabilities are positively related to inside-out capabilities.

\subsubsection{Findings about the (SC dimension level) and the (IOC) Construct}

The table below (Table 5) shows the model summary of the stepwise regression results for the (SC) dimensions (purchasing, customer order processing, strategy development, and information dissemination on all the dimensions of the (IOC) construct (packing, finished goods warehousing, inventory control-outbound, and outbound transportation).

Table 5. Dimension level stepwise regression results model summary for (SC) dimensions on IOC

\begin{tabular}{lllllllll}
\hline Step & $\mathrm{R}$ & $\mathrm{R}^{2}$ & $\mathrm{R}_{\text {adj }}^{2}$ & $\Delta \mathrm{R}_{2}$ & $\mathrm{~F}_{\text {chg }}$ & Sig $\mathrm{F}_{\text {change }}$ & $d f_{1}$ & $d f_{2}$ \\
\hline 1- customer order processing & 0.384 & 0.140 & 0.140 & 0.147 & 19.089 & 0.000 & 1 & 222 \\
2- purchasing & 0.461 & 0.212 & 0.205 & 0.212 & 27.229 & 0.000 & 2 & 221 \\
3- strategy development & 0.524 & 0.274 & 0.276 & 0.274 & 38.163 & 0.000 & 3 & 220 \\
4- information dissemination & 0.536 & 0.287 & 0.284 & 0.287 & 89.363 & 0.000 & 4 & 119 \\
\hline
\end{tabular}


Table 6. Coefficients for (SC) dimensions on the construct (IOC)

\begin{tabular}{llll}
\hline $\mathrm{B}$ & $\beta$ & $\mathrm{T}$ & Sign \\
\hline 0.317 & 0.384 & 4.059 & 0.000 \\
0.459 & 0.461 & 5.218 & 0.000 \\
0.678 & 0.524 & 6.178 & 0.000 \\
0.256 & 0.536 & 9.458 & 0.000 \\
\hline
\end{tabular}

Based on the stepwise regression results that are shown in Table 5 which indicate an overall model of all the four dimensions of the (SC) construct (namely purchasing, customer order processing, strategy development, and information dissemination) that reasonably predict the (IOC) construct. A summary of regression coefficients, presented in Table 6, indicates that all the dimensions of (SC) have a strong positive relationship with all the dimensions of the (IOC) at the $5 \%$ significance level which statistically predicts the (IOC) construct in the following order:

- the most important dimension is information dissemination which has a strong significant positive correlation with all the dimensions of the (IOC) construct with $(\beta=0.536 ; \mathrm{p}=.000<.05)$ and explains $28.4 \%$ $\left(\mathrm{R}^{2}\right.$ adj) of the variance in (IOC) construct $(\mathrm{F}=89.363, \mathrm{p}<0.000)$. This result confirms that the greater the respondents gets interested in focusing the logistic functions on adopting the latest information system technologies, and in providing meaningful information regarding the competitive environment, the greater the improvement in the all the dimensions of the (IOC) construct will occur.

- $\quad$ strategy development follows information dissemination and has a strong significant positive correlation with all the dimensions of the (IOC) with $(\beta=0.524 ; \mathrm{p}=.000<.05)$, and explains $28.4 \%\left(\mathrm{R}^{2} \mathrm{adj}\right)$ of the variance in the $(\mathrm{IOC})$ construct $(\mathrm{F}=38.163, \mathrm{p}<0.000)$. This result interpreted that the greater the conviction of the respondents on directing their attention towards achieving highly integrated logistics strategy with the strategic plans of other areas, and on giving attention to logistics operations in supporting the strategic plan and in creating customer value, the greater the improvement in all the dimensions of the (IOC) construct.

- purchasing follows strategy development and has a strong significant positive correlation with all the dimensions of the (IOC) construct with $(\beta=0.461 ; \mathrm{p}=.000<.05)$, which explains $20.5 \%\left(\mathrm{R}^{2} \mathrm{adj}\right)$ of the variance in the $(\mathrm{IOC})$ construct $(\mathrm{F}=27.229, \mathrm{p}<0.000)$. This finding reflects to what extent the respondents in these companies have enough interest in supporting the strategic purchasing activities that focus on preparing strategic values to their companies, in determining the specification (in terms of required quality and quantities) of the goods and services that need to be bought, in selecting the most suitable supplier, in placing the order with the selected supplier, and in monitoring and controlling the order for improving all the dimensions of the (IOC) construct.

- customer order processing follows purchasing and has a significant positive correlation with all the dimensions of the (IOC) construct with $(\beta=0.384 ; \mathrm{p}=.000<.05)$, and explains $14 \%\left(\mathrm{R}^{2}\right.$ adj) of the variance in the $(\mathrm{IOC})$ construct $(\mathrm{F}=19.089, \mathrm{p}<0.000)$. This result indicates that the greater the respondents offer high flexibility in developing the delivery schedules, and in delivering the orders on time as defined by the customers, the greater the improvement in the all the dimensions of the (IOC) construct will occur.

Based on this interpretation, the model is sufficient to support and accept hypothesis $\left(\mathrm{H}_{2}\right)$ which states that spanning capabilities are positively related to inside-out capabilities.

\subsubsection{Findings about the (SC Dimension Level) and the (OIC) Construct}

The table below (Table 7) shows the model summary of the stepwise regression results for the (SC) dimensions (purchasing, customer order processing, strategy development, and information dissemination) on the (OIC) construct (inbound transportation, material warehousing, inventory control- inbound and production support).

Table 7. Dimension level stepwise regression results model summary for (SC) dimensions on OIC

\begin{tabular}{lllllllll}
\hline Step & $\mathrm{R}$ & $\mathrm{R}^{2}$ & $\mathrm{R}_{\text {adj }}^{2}$ & $\Delta \mathrm{R}_{2}$ & $\mathrm{~F}_{\text {chg }}$ & $\mathrm{Sig} \mathrm{F}_{\text {change }}$ & $d f_{1}$ & $d f_{2}$ \\
\hline 1- purchasing & 0.195 & 0.151 & 0.148 & 0.151 & 16.574 & 0.000 & 1 & 222 \\
2- information dissemination & 0.289 & 0.184 & 0.173 & 0.184 & 39.163 & 0.000 & 2 & 221 \\
3- customer order processing & 0.481 & 0.231 & 0.227 & 0.231 & 56.363 & 0.000 & 3 & 220 \\
\hline
\end{tabular}


Table 8. Coefficients for (SC) dimensions on the construct (OIC)

\begin{tabular}{llll}
\hline $\mathrm{B}$ & $\beta$ & $\mathrm{T}$ & Sign \\
\hline 0.235 & 0.195 & 3.161 & 0.002 \\
0.193 & 0.289 & 6.295 & 0.000 \\
0.163 & 0.481 & 8.165 & 0.000 \\
\hline
\end{tabular}

According to the stepwise regression results that are shown in the above table, the findings in the sample of Egyptian companies substantiate the existence of only three dimensions out of four of the overall model of the (SC) construct (namely purchasing, customer order processing, and information dissemination) that reasonably predict the (OIC) construct. A summary of the regression coefficients presented in Table 8 indicates that three dimensions out of four of (SC) construct have a strong positive relationship with all the dimensions of the (OIC) construct at the 5\% significance level which statistically predicts the (OIC) construct in the following order:

First,the most important dimension is the customer order processing COP which has a strong significant positive correlation with all the dimensions of the (OIC) construct with $(\beta=0.481 ; \mathrm{p}=.000<.05)$ and explains $22.7 \%\left(\mathrm{R}^{2}\right.$ adj) of the variance in the $(\mathrm{OIC})$ construct $(\mathrm{F}=56.363, \mathrm{p}<0.000)$. This result means that the greater the respondents get concerned with offering the reliability of order processing times, with supporting the submitted orders and delivering them on time, and with responding to provide an accurate information to the customers about their orders, the greater the improvement in all the dimensions of the (OIC) construct will occur.

Second, information dissemination follows customer order processing and has a significant positive correlation with all the dimensions of the $(\mathrm{OIC})$ construct with $(\beta=0.289 ; \mathrm{p}=.000<.05)$ and explains $17.3 \%\left(\mathrm{R}^{2}\right.$ adj $)$ of the variance in the $(\mathrm{IOC})$ construct $(\mathrm{F}=39.163 ; \mathrm{p}<0.000)$. This result means that the greater the respondents get interested in investing in information systems for managing logistic activities in order to provide useful information on the requirements of individual markets/clients, the greater the improvement in all the dimensions of the (OIC) construct will occur.

Third, Purchasing follows information dissemination and has a significant positive correlation with all the dimensions of the (OIC) construct with $(\beta=0.195 ; \mathrm{p}=.000<.05)$ and explains $14.8 \%\left(\mathrm{R}^{2}\right.$ adj) of the variance in the (IOC) construct $(\mathrm{F}=16.574, \mathrm{p}<0.000)$. This result means that the greater the respondents get interested in obtaining materials that meet specifications, in selecting and evaluating suppliers effectively, in keeping excellent communications with them, and in performing the purchasing function with high quality manners that maximizes their company's overall viability, the greater the improvement in all the dimensions of the (OIC) construct will occur.

In addition, there is only one dimension out of the four dimensions of the (SC) construct, strategy development, which does not predict any of the (OIC) dimensions. It is thus evident that none of the items of strategy development (e.g., input for logistics personnel that supports the strategy development, and the administration of logistics operations in a manner that supports the strategic plan of the company) contributes significantly to the prediction of the dimensions of the (OIC) construct.

This model supports and partially accepts hypothesis $\left(\mathrm{H}_{3}\right)$ which states that spanning capabilities are positively related to outside-in capabilities.

\subsubsection{Findings about the (IOC Dimension Level) and the (BP) Construct}

The table below (Table 9) shows the model summary of the stepwise regression results of the (IOC) dimensions (packing, finished goods warehousing, inventory control-outbound, and outbound transportation) on the (BP) construct (perceived product value, customer loyalty, market performance and financial performance).

Table 9. Dimension level stepwise regression results model summary for (IOC) dimensions on BP

\begin{tabular}{lcccccccc}
\hline Step & $\mathrm{R}$ & $\mathrm{R}^{2}$ & $\mathrm{R}_{\text {adj }}^{2}$ & $\Delta \mathrm{R}_{2}$ & $\mathrm{~F}_{\text {chg }}$ & Sig $\mathrm{F}_{\text {change }}$ & $d f_{1}$ & $d f_{2}$ \\
\hline 1- packing & 0.341 & 0.116 & 0.112 & 0.116 & 29.181 & 0.000 & 1 & 222 \\
2-finished goods warehousing & 0.248 & 0.150 & 0.138 & 0.150 & 12.943 & 0.000 & 2 & 221 \\
3- inventory control-outbound & 0.292 & 0.125 & 0.117 & 0.125 & 20.642 & 0.000 & 3 & 220 \\
4- outbound transportation & 0.464 & 0.219 & 0.215 & 0.215 & 60.843 & 0.000 & 4 & 119 \\
\hline
\end{tabular}


Table 10. Coefficients for IOC dimensions (P, FGW, ICO, and OT) on (P)

\begin{tabular}{cccc}
\hline $\mathrm{B}$ & $\beta$ & $\mathrm{T}$ & Sign \\
\hline 0.140 & 0.341 & 5.402 & 0.000 \\
0.226 & 0.248 & 3.926 & 0.000 \\
0.231 & 0.292 & 4.543 & 0.000 \\
0.236 & 0.464 & 7.800 & 0.000 \\
\hline
\end{tabular}

Based on the results that are shown in Table 9, an overall model of all the four dimensions of the (IOC) construct (packing, finished goods warehousing, inventory control-outbound, and outbound transportation), in which those dimensions reasonably predict the (BP) construct. A summary of regression coefficients presented in Table 10 indicates that all the dimensions of the (IOC) have a strong positive relationship with all the dimensions of the (BP) at the 5\% significance level which statistically predicts the (OIC) construct in the following order:

First, the most important dimension is outbound transportation, which has a strong significant positive correlation with all the dimensions of the (BP) with $(\beta=0.464 ; \mathrm{p}=.000<.05)$ and explains $21.5 \%$ ( $\mathrm{R}^{2}$ adj) of the variance in the (BP) construct $(\mathrm{F}=60.843, \mathrm{p}<0.000)$. This result reflects to what extent the managers of these companies have sufficient conviction of the importance of the overall quality, the role of the outbound transportation function and the costs of improving the business performance dimensions (perceived product value, customer loyalty, market performance and financial performance) through focusing on providing on time responses to inquiries, on meeting delivery schedules, and on delivering shipments under the agreed upon conditions with the customers.

Second, the packing dimension follows outbound transportation and has a significant positive correlation with all the dimensions of the $(\mathrm{BP})$ construct with $(\beta=0.341 ; \mathrm{p}=.000<.05)$ and explains $11.2 \%\left(\mathrm{R}^{2}\right.$ adj) of the variance in the (BP) construct $(\mathrm{F}=29.181, \mathrm{p}<0.000)$. This result indicates that the managers of these companies have adequate recognition of the role played by the function of packing in improving the business performance $\mathrm{P}$ (perceived product value, customer loyalty, market performance and financial performance), by directing their attention towards the overall quality with the aim of meeting the packaging specifications of their customers, of minimizing damage to their final products, of facilitating efficient handling and transporting of their outputs, of sustaining their production plans, of responding to special requests, and of accurate and distinguishable labeling on their packaged products.

Third, inventory control-outbound follows packing and has a significant positive correlation with all the dimensions of the (BP) construct with $(\beta=0.292 ; \mathrm{p}=.000<.05)$ and explains $11.7 \%\left(\mathrm{R}^{2}\right.$ adj) of the variance in the (BP) construct $(\mathrm{F}=20.642, \mathrm{p}<0.000)$. This finding indicates the awareness of the managers of these companies of the extent of the importance of the overall quality of finished goods inventory control on improving the business performance $\mathrm{P}$ (perceived product value, customer loyalty, market performance and financial performance) through directing their attentions towards focusing on the accuracy of records concerning the quantities of raw materials and finished goods on-hand, on the location of finished goods in the warehouse, on the length of time required to update the finished goods inventory records, and on maximizing the overall revenue.

Forth, finished goods warehousing follows inventory control-outbound and has a significant positive correlation with all the dimensions of the (BP) construct with $(\beta=0.248 ; \mathrm{p}=.000<.05)$ and explains $13.8 \%\left(\mathrm{R}^{2}\right.$ adj) of the variance in the $(\mathrm{BP})$ construct $(\mathrm{F}=12.943, \mathrm{p}<0.000)$. This result indicates that the managers of these companies have adequate recognition of the critical role of the finished goods warehousing function through practicing their activities with overall quality in picking and assembling customer orders accurately, responding promptly to customer requests, and reducing the rates of ware housing the damaged finished goods, with the aim of improving their companies' business performances P (perceived product value, customer loyalty, market performance and financial performance). In light of the above results, this model is sufficient to support and accept hypothesis $\left(\mathrm{H}_{4}\right)$ which states that inside-out capabilities are positively related to business performance a) performance product value, b) customer loyalty, c) market performance, d) financial performance.

\subsubsection{Findings about (SC Dimension Level) and the (BP) Construct}

The table below (Table 11) shows the model summary of the stepwise regression results of the (SC) dimensions (purchasing, customer order processing, strategy development and information dissemination) on all the dimensions of the (BP) construct (perceived product value, customer loyalty, market performance and financial 
performance).

Table 11. Dimension level stepwise regression results model summary for (SC) dimensions on BP

\begin{tabular}{llllllllc}
\hline Step & $\mathrm{R}$ & $\mathrm{R}^{2}$ & $\mathrm{R}_{\text {adj }}^{2}$ & $\Delta \mathrm{R}_{2}$ & $\mathrm{~F}_{\text {chg }}$ & Sig $\mathrm{F}_{\text {change }}$ & $d f_{1}$ & $d f_{2}$ \\
\hline 1- purchasing & 0.177 & 0.031 & 0.027 & 0.031 & 7.145 & 0.008 & 1 & 222 \\
2- customer order processing & 0.135 & 0.018 & 0.014 & 0.018 & 4.120 & 0.044 & 2 & 221 \\
3- strategy development & 0.133 & 0.018 & 0.013 & 0.013 & 4.010 & 0.046 & 3 & 220 \\
4- information dissemination & 0.381 & 0.145 & 0.136 & 0.145 & 17.102 & 0.000 & 4 & 119 \\
\hline
\end{tabular}

Table 12. Coefficients for (SC) dimensions on the construct (BP)

\begin{tabular}{llll}
\hline B & $\beta$ & $\mathrm{t}$ & Sign \\
\hline 0.133 & 0.177 & 2.673 & 0.008 \\
0.104 & 0.135 & 2.030 & 0.044 \\
0.130 & 0.133 & 2.002 & 0.046 \\
0.372 & 0.381 & 4.136 & 0.000 \\
\hline
\end{tabular}

The stepwise regression results indicate that there is only one dimension out of four of the overall model of the (SC), which is information dissemination and that it statistically predicts all the dimensions of the (BP) construct at the $5 \%$ significance level.

A summary of regression coefficients presented in Table 12 indicates that information dissemination has a significant positive relationship with all the dimensions of the (BP) construct with $(\beta=0.381 ; \mathrm{p}=.000<.05)$ and explains $13.6 \%\left(\mathrm{R}^{2}\right.$ adj) of the variance in the $(\mathrm{BP})$ construct $(\mathrm{F}=17.102, \mathrm{p}<0.000)$. This result reflects to what extent the managers of these companies consider this dimension as a crucial dimension for the rapid spread of the different data needed along the supply chain to meet customer requirements, to quickly coordinate the sourced, to make and deliver operations that enable quick reactions in order to satisfy changing customer needs, to quickly develop strategies based on the coordination and integration of information along the value chain, and to seek to become more responsive to changing market conditions by streamlining, knowledge work teams and up-to-date marketing information to every node within the organization. Besides, they are interested in continuous dissemination of the new information to key individuals within organizations to improve performance since quality and timely information help the top management in decision making, improve efficiency and effectiveness, respond to customers 'changing needs faster, and give manufacturers access to more accurate demand information and customer sales data. In addition, These managers from various functional departments communicate and collaborate within the organization as well as with their partners to improve market shares, return of total assets, annual sales growth, total product value to the customer, meeting quality standards set by the customer, understanding customer needs, and retention of loyal customers.

Since that $\left(\mathrm{R}^{2}\right.$ adj) must be at least 0.10 (i.e. the given independent variables must explain at least $10 \%$ of the variance in dependent variables), and that the results made it clear that $\left(\mathrm{R}^{2} \mathrm{adj}\right)$ for the three dimensions of the (SC) construct (purchasing $=0.031$, customer order processing $=0.018$, strategy development $=0.013$ ) are less than 0.10 ; therefore, these three dimensions cannot contribute significantly to the prediction of any of the dimensions of the (BP) construct. However, these three dimensions have week positive relationship but not significant at the $5 \%$ significance level with all the dimensions of the (BP) construct; and arranged in their descending order: purchasing $(\beta=0.177 ; \mathrm{p}=0.008)$, customer order processing $(\beta=0.135 ; \mathrm{p}=0.044)$ and strategy development $(\beta=0.133 ; \mathrm{p}=0.046)$.

First,It is thus evident that the managers of these companies does not have sufficient conviction on the importance of any of the items of the first dimension, purchasing, for improving any one of the dimensions of the (BP) construct through practicing this function, or maybe they don't have enough capabilities to determine how much to buy, the selected supplier(s), the level of quality delivered, the price paid, or when and where the goods will be presented to satisfy clients. 
Second, from the respondents' points of view, none of the items of customer order processing dimension can contribute in improving any of the business performance dimensions. This finding indicates that the managers of these companies do not give enough attention regarding how to manage the time between receiving the orders and delivering them to the customers, or maybe they are less interested in how to manage the activities, regarding processing the orders, which confirm their customers' demand and show the impact of practicing these activities effectively on increasing both customer loyalty and perceived product value; leading to improving both market and financial performance.

Third, based on the respondents' answers, the results show that none of the items of strategy development can contribute in improving any one of the dimensions of the (BP) construct. These results may reflect, first, the absence of a clear vision from the managers of these companies on the strategy for the tasks associated with managing supply chain activities; second, the importance of achieving the integration between this strategy and the strategic plans of other areas on one hand, and between this strategy and the company's strategy on the other hand; and finally impact of this integration on their companies' performance.

Based on the interpretations of this construct, this model is not sufficient to support these relations and rejects hypothesis $\left(\mathrm{H}_{5}\right)$ which states that the spanning capabilities are positively related to business performance: a) perceived product value b) customer loyalty c) market performance d) financial performance.

\section{Discussion}

This research provides an empirical justification for a framework that explores the relationship among the three constructs of the (SCMC) and the (BP) construct.

The reliability coefficients for all the constructs are greater than 0.70 , which are considered acceptable. All the dimensions of the (OIC) construct has higher reliability coefficients (above 0.80) compared to the (IOC) and the (SC) constructs. In addition, the results found that the highest reliability coefficient regarding the (OIC) construct is the material warehousing dimension's Cronbach's Alpha coefficient (0.810). These results are inconsistent with the findings of the study that is prepared by (Tracey et al., 2005), who found that the reliability coefficients of all the dimensions of the (OIC, IOC, and SC) constructs are higher than (0.8) except the inbound transportation dimension in the (OIC) construct whose reliability coefficient is $(0.79)$. Whereas the highest reliability coefficients are of the inventory control dimension in the (OIC) construct and the packing dimension in (IOC) construct, which is $(0.89)$ for both of them. The results found that the financial performance dimension has the highest reliability coefficient (0.792) in the (BP) construct, which is consistent with Knight et al., (2008); Fantazy et al. (2009); Cook et al. (2011); Kelly et al. (2013), and that customer loyalty, market share and perceived product has the lower reliability coefficients $0.785,0.787$ and 0.789 respectively.

The descriptive statistics' results of the current study showed that the most important dimension in the (OIC) construct is material warehousing with a mean score (3.9009). This result agreed with the results that are provided by (Tracey et al., 2005) in which material warehousing has the highest mean scores across the industries (3.551), and also agreed with the results of (Zailani et al., 2009; Kempkes et al., 2010) which reported the increasing need for business enterprises to embrace effective inventory warehousing management practices as a strategy to improve their competitiveness, customer services and market share. The current study revealed that the product support dimension in the (OIC) construct has the least mean score (3.7201), this result is supported by (Tracey et al., 2004; Rodrigues et al., 2008); however, these findings are inconsistent with the results that are provided by (Tracey et al., 2005) in which the inbound transportation dimension has the least mean score (3.315). The results of the sample of Egyptian companies showed that inventory control-outbound is a key dimension in the IOC construct with the highest mean score (3.8812). This result is supported by (Mogere et al., 2013) who found that the flexibility in the response to the markets and on time delivery to the customers has the highest mean scores (3.75 and 4.35 respectively). While this result differed from the results that are provided by (Tracey et al., 2005) in which they found that finished goods warehousing has the highest mean score (3.659) in the IOC construct. Although the result revealed that the packing dimension has the least mean score (3.7558), it isn't compatible with the results that are provided by (Tracey et al., 2005) who found that outbound transportation dimension has the least mean score (3.407) in the (IOC) construct. Despite, the current research revealed that information dissemination has the highest mean score (3.9705) in the (SC) construct, which is supported by (e.g., Shang et al., 2005; Cook et al., 2011; Prajogo et al., 2012), the result is inconsistent with both (Tracey et al., 2005), who found that this dimension has the lowest mean score (3.079), and (Elkhouly et al., 2012). On the other hand, the results showed that the strategy development dimension has the lowest mean score (3.9304) in the (SC) construct, this finding is consistent with (Manders, 2009; Whitten et al., 2012) that considered it as the key of successful SCM; however, it didn't match with (Tracey et al., 2005) who found that 
the highest mean score (3.950) is customer order processing dimension. The results of the current research revealed that there is a conflict with the previous studies related to the indicators that are used to measure the (BP) construct; and that is the case because the results of the current study showed that the most important dimension of the (BP) construct is the financial performance with a mean score (4.0598), which is supported by previous studies including ( Knight et al., 2008; Kelly et al., 2013; Bavarsad et al., 2013), but it is inconsistent with (Tracey et al., 2005) who found that it has the lowest mean score (3.490); and also because the current results showed that the customer loyalty dimension has the lowest mean score (3.4643) in the (BP) construct, but this result is contradicted with (Tracey et al., 2005; Sanchez et al., 2005 in Fantazy et al., 2009; Williams et al., 2002 in Flynn et al., 2010) who considered it as one of the critical dimensions in the SCM practices for improving the business performance.

The hypotheses testing results showed that four out of the five hypotheses, which are proposed in this study, are accepted.

Regarding the first hypothesis, the sample of Egyptian companies clearly showed that the inventory control-inbound dimension explained the highest percentage of the variance $45.3 \%\left(\mathrm{R}^{2}\right.$ adj) in the (IOC) construct and has a strong positive relationship with all the dimensions of the (IOC) construct with $(\beta=0.675)$. This result reflected the perception and efficiency of the managers in these companies to follow the best practices in performing the activities, which are related to the management and the control of the inventory; through the application of a strategy which is based on the reduction of the cost of inventory obsolescence. Besides, these managers truly work towards responding to their customers' real needs, making scheduling and shop loading more efficiently, narrowing the gap between production planning and stock replacement, and record-keeping accuracy for better inventory management. In addition, they consider the inventory strategy as a part of the overall strategic business plan through an accurate record of shipping and receiving the products on time, keeping the company's supply chain running smoothly and efficiently, shortening the lead times, improvement and simplicity, quick response, and integrating the supply chain with inventory control management; which will affect the capacity imbalances and transaction costs (Management \& Development Center, 2011). These findings are not totally surprising; since some earlier studies reported similarities which are related to the importance of the inventory control-inbound dimension (e.g., Dimitrios, 2008; Augustine et al., 2013; Ng'ang'a, 2013; Ann I et al., 2014), which found that inventory alone accounts for as much as $30 \%$ of the organization's invested capital. However, this finding is in disagreement with (Tracey et al., 2005) who found that the most important dimension in the (OIC) construct is the material warehousing dimension with Lambda Coefficient (0.93). The results revealed that the inbound transportation dimension explained the lowest percentage with $13.6 \%$ of the variance in the (IOC) construct in the sample of Egyptian companies. This result is similar to the view of (Tseng et al., 2005; Rodrigues et al., 2008). Whilst, this result is not matched with (Christopher \& Lee, 2004) who considered inbound transportation dimension as a critical activity to the overall supply chain performance, the created customer value and the firm performance. It represents the most important economic activity among the components of business logistics systems; and on the average, it is accounted for $6.5 \%$ of the market revenue and $44 \%$ of the logistics costs. The results of the production support dimension in the sample of Egyptian companies are contrary to what is expected, as these results showed that this dimension has no capability to explain the variance of any of the dimensions of the (IOC) construct because ( $\mathrm{R}^{2}$ adj) is less than $10 \%$. This result is not consistent with the results of (Tracey et al., 2005; Senapat et al., 2012; Lwiki et al., 2013; Sukati et al., 2013; Mekel et al., 2014) as they concluded that the empirical results revealed to what extent the capabilities of the production system are able to rapidly respond to the changes in product demanded volume by the customers. They considered this to be the most important indicator of production support in supply chain processes because it helps to reduce the risk in the supply chain in order to reap the benefits of a leaner operation, to ensure that the supply is kept flowing to meet the demand, to coordinate the shipments of raw materials based on the production schedules, and to reduce the lead times in order to avoid the bottleneck of operations. These results provide an adequate proof that three out of the four dimensions of the (OIC) construct are positively related to the (IOC) construct; therefore depending on these results, the hypothesis $\left(\mathrm{H}_{1}\right)$ is partially accepted.

Among the interesting observations in the sample of Egyptian companies, the results revealed that all the four dimensions of the (SC) construct reasonably predict all the dimensions of the (IOC) construct. The results found that $28.4 \%$ of the variance in the (IOC) construct is explained by the information dissemination dimension. This result is matched with the interpretation of the research to the high explanation of this dimension, and is in agreement with those of many other studies (e.g., Shang et al., 2005; Carr et al., 2007; Rodrigues et al., 2008; Giovanni, 2009; Fantazy et al., 2009; Elkhouly et al., 2012; Prajogo et al., 2012; Noraini et al., 2014), which found that information-based capability has the most critical impact on logistics performance through connecting 
all the components, activities and operations in the company, enabling material flow, reducing inventory costs, and making reliable delivery. However, this finding is in disagreement with (Tracey et al., 2005) who found that purchasing is the most important dimension in the (SC) construct with Lambda coefficient (0.731).

Furthermore, $27.6 \%$ of variance in the (IOC) construct is explained by the strategic development dimension, while $20.5 \%$ of variance is explained by the purchasing dimension. The results in the sample of Egyptian companies elucidated that customer order processing dimension in the (SC) construct explained the lowest percentage of the variance in the (IOC) construct with (14\%). This result is supported by (Tracey et al., 2005), who found that this dimension has the lowest Lambda coefficient $(0.60)$ comparing with the other dimensions in the (SC) construct, and is in agreement with (Sukati et al., 2013), who found that the order processing dimension has the lowest mean score (3.74). However, another previous studies such as (Stadtler, 2005; Arshinder et al., 2008; Perr, 2012; Muzumdar et al., 2013), which found that this dimension is an indispensable part of the supply chain. These results provide an adequate proof that all the dimensions of the (SC) construct are positively related to the (IOC) construct; therefore, depending on these results, the hypothesis $\left(\mathrm{H}_{2}\right)$ is accepted.

In addition, the findings revealed that the purchasing dimension explains the lowest percentage of variance of all the dimensions of the (OIC) construct in the sample of Egyptian companies. This result clarified that the sample of the Egyptian companies suffer from number of problems such as the lack of the mechanisms of competition, the difficulties that the managers of these companies are faced in achieving the cooperation and coordination between the different departments in the company because of the bureaucratic practices in the public industrial sector, the purchasing systems are centralized in decision making, the scarcity of financial resources, and the instability of economic and political conditions (Management \& Development Center, 2011). This finding showed some similarities with previous studies such as (Paulraj et al., 2007; Knight et al., 2008; Lawson et al., 2009; Kadima et al., 2013; Noor et al., 2013; Wahome, 2013), which found that purchasing dimension is associated with product specification, production schedule, order cycle time, replenishment stock, time delivery, demand uncertainty and customer satisfaction in terms of cost and quality. However, this result is in disagreement with (Tracey et al., 2005), who disclosed that purchasing dimension has the highest influence in the (SC) construct on all the dimensions of the (OIC) construct with Lambda coefficient (0.73). In particular, the difference between the sample of Egyptian companies and the most previous studies is that strategic development dimension has no capability to explain the variance of any of the dimensions of the (OIC) construct. This finding is due to increasing the political and economic pressure, the difficulties in adapting to the rapid and continuous transformation in the country, and the paucity of information among decision-makers in these companies prevents them from the possibility of the development of the supply chain strategy in light of the prevailing climate in Egypt (Herrera, Selim, \& Zaki, 2010). This finding not matched with the findings of prior researches (Tracey et al., 2005; Green Jr et al., 2008; Lawsaon et al., 2009; Naude et al., 2011; IshtiaqIshaq et al., 2012; Noraini et al., 2014), where strategic development dimension is found to be positively associated with all the dimensions of the (OIC) construct. The results found that the most important dimension in the (SC) construct in the sample of Egyptian companies is customer order processing that explained the higher percentage with 22.7\% of the variance in the (OIC) construct. This result is in agreement with (Sundram et al., 2011; Meisel et al., 2011; Noraini et al., 2014), who supported the importance of dealing with the customer complaints through processing their orders. Also, it is in agreement with (Perry, 2012), who concluded many other studies that supported this result (see., Shapiro, Rangan, \& Sviokla, 1992; Lin \& Shaw, 1998; Croxton , 2003; Forslund, 2006; Forslund, 2007; Lambert, 2008). However, this finding is in disagreement with (Tracey et al., 2005), who disclosed that this dimension is more important than both information dissemination dimension and purchasing dimension in its impact on all the dimensions of the (OIC) construct. Based on these results that substantiate three out of four dimensions of the (SC) construct are positively related to the (OIC) construct, therefore depending on these results, the hypothesis $\left(\mathrm{H}_{3}\right)$ is partially accepted.

Regarding the fourth hypothesis, the sample of Egyptian companies clearly showed that the outbound transportation dimension explained the highest percentage of the variance $21.5 \%\left(\mathrm{R}^{2}\right.$ adj) in the (IOC) construct and has a strong positive relationship with all the dimensions of the (PB) construct with $(\beta=0.464)$. This finding is in agreement with (Tracey et al., 2005; Rodrigues et al., 2008; Green Jr et al., 2008; Meisel et al., 2011; Mekel et al., 2014), who found carrier freight rates, the load and distance of the shipments, transportation schedule, and the order delivery time have strong impact on improving the financial performance, market performance, customer loyalty, and perceived product value. The results also showed that the finished goods warehousing dimension in the (SC) construct has a week positive relationship with all the dimensions of the (PB) construct with $(\beta=0.248)$ and explained $13.8 \%\left(\mathrm{R}^{2}\right.$ adj) of the variance of the (BP) construct. This result revealed the nature of the interim phase in Egypt and the direct negative effects on the managers of these companies which 
compelled them on preparing the strategic goals to their companies depending on sacrificing the long-term profits in order to acquire short-term profits and to enhance their market share and satisfying their customers. This finding is in agreement with (Chow et al., 2006; Baker, 2007; Gu et al., 2007), who found that the warehousing of finished goods has become a challenge for the warehouse managers to make decisions in the short time in order to respond to the customers' orders due to the lack of both the time and the quality information. However, this finding is in disagreement with (Tutuncu et al., 2008; Ai-Chin et al., 2011), who found that there is a strong positive correlation between the internal and external customer satisfaction with focusing on the quick response to processing the orders. But this result is in disagreement with (Sukati et al., 2011), who found that the achievement of strategic goals of the companies to expand their market share and to improve the profitability is the outcome of the efforts of managing these companies in enhancing the quick responses to the customers' orders and in delivering value to them. The result found that the packing dimension in the (IOC) construct has a positive relationship with all the dimensions of the (BP) construct with $(\beta=0.341)$, but explained the lowest percentage with $11.2 \%\left(\mathrm{R}^{2}\right.$ adj) of the variance of the (BP) construct. This finding is consistent with (Tracey et al., 2005), who found that the packing has the lowest lambda coefficient (0.68) comparing with all the dimensions in the (IOC) construct. Whilst, there is some similarity between this finding and the study provided by (Rumanathan, 2014), where the supply chain partners in the packaging industry can extend their partnership to increase the profit, to reduce the lead time and to improve the customers' satisfaction. This result also is in agreement with (Azad et al., 2013; Chaudhary, 2014; Wang et al., 2014), who found that the packaging style has a sturdy impact on the consumers' perception of product quality. However, this finding is in disagreement with (Abdalkrim et al., 2013; Silayoi et al., 2007), who found that there is no significant statistical effect of the role of the packing on the consumer's perception of product quality at the time of purchase and also is in disagreement with (Zhang et al., 2010), who found that the customer loyalty dimension has a positive relationship with customer retention dimension in the consumer packaged good. These results provide an adequate proof that all the dimensions of the (IOC) construct are positively related to the (BP) construct; therefore, depending on these results, the hypothesis $\left(\mathrm{H}_{4}\right)$ is accepted.

The illogical observations in the sample of Egyptian companies that there is only one dimension out of the four dimensions of the (SC) construct, information dissemination, has a positive relationship with all the dimensions of the (PB) construct with $(\beta=0.381)$ and explained $13.6 \%\left(\mathrm{R}^{2}\right.$ adj) of the variance of the (BP) construct. This finding is in contrast to the common argument that reported by (Tracey et al., 2005; Li et al., 2005; Trkman et al., 2006; Tutuncu et al., 2008; Lee et al., 2009; Cook et al., 2011; Prajogo et al., 2012; Kelly et al., 2013; Kumar et al., 2013; Noraini et al., 2014), who found that the SCM capabilities have a relationship with the business performance dimensions. Whilst, the result showed that the purchasing dimension in the (SC) construct has a weak positive relationship with all the dimensions of (BP) construct with $(\beta=0.177)$ and didn't contribute to the prediction of any of the dimensions of the (BP) construct in the sample of Egyptian companies. This result reflects that to what extent the administrative systems in the sample of Egyptian companies are suffering from the complexity of the governmental action, the complicated control systems and the evasion from the responsibility that refers to the need to restructuring these administrative systems and to modifying the control systems. Besides, the weak purchasing power for the low-income customers; the intense competition; the lack of controlling the production systems; the weak management, the scarcity of supplying the skilled and trained workers and the inability to pay high wages (Herrera et al., 2010). This finding is in disagreement with (Tracey et al., 2005), who supported that the purchasing is the most critical dimension in the (SC) construct to influence on all the dimensions of the (BP) construct. Also, this result is in disagreement with (Noor et al., 2013; Van Weele et al., 2014; Kumar et al., 2014), who found that the purchasing planning has the highest positive correlation with markets and this result is in disagreement with (Kamel et al., 2010), who found that there is appositive relationship between the purchasing dimension and both of the financial performance and customer satisfaction. In addition, this result is in disagreement with (Knight et al., 2008), who found that there is a positive relationship between purchasing practices and financial performance in terms of return on assets and the ration of market value of the firm. Finally, this result is in disagreement with (Tutuncu et al., 2008), who found that there is a positive relationship between stable procurement through network and internal and external customer satisfaction with ( $\mathrm{r}=0.704)$.

The results found that the customer order processing dimension in the (SC) construct has a week positive relationship with all the dimensions of the (BP) construct with $(\beta=0.135)$ and didn't contribute to the prediction of any of the dimensions of the (BP) construct in the sample of Egyptian companies. This finding is due to set of factors such as the ineffectiveness regulations of consumer protection, the weakness of the market institutions, the concentration of the market, the insufficient information that is exchanged between the production and the markets, the using of non-structured channels in marketing. In addition, the misguided policies to maintain the 
reduction of production costs without paying attention to the elements of production quality, the bureaucratic regulations in the governmental sector that causes the inability to respond quickly to customer requirements and the difficulty of the timetables commitment to deliver products in a timely manner to the customers (Herrera et al., 2010). This finding is in disagreement with previous studies that found strong relationship between customer order processing with the firm performance (Green Jr et al., 2008), with the financial and the customer loyalty (Fantazy et al., 2009), with the market and the financial performance and delivering value to customer (Sukati et al., 2011), and finally, with on time delivery and market share (Florian et al., 2013; Noor et al., 2013).

While the results revealed that the strategy development dimension in the (SC) construct has a week positive relationship with all the dimensions of the (BP) construct with $(\beta=0.135)$ but didn't contribute to the prediction of any of the dimensions of the (BP) construct in the sample of Egyptian companies. These results reflect the insufficiency in some of the administrative practices of these companies represented in the absence of the necessary information for developing the planning programs, the short time required for the mechanisms of implementing these programs as an outcome of financial limitations due to insufficient budgets, and the polices are inadequate or poorly integrated plans for the achievement of a sustainable supply chain strategy. Further, developing strategy requires large investments while the financial returns are not attractive (Herrera et al., 2010).

This finding is in agreement with (Rodrigues et al., 2008), who disputed that developing supply chain strategy is hard work because of uncertainty of time, speed, agility, flexibility, and quality of supply chain information flow. Also, this result is in agreement with (Green Jr et al., 2008), who found that the strategy of the SCM and the logistics performance didn't have a direct impact on the financial performance. Whilst, various prior studies proved that there is a positive significant relationship between the strategy of SCM and both of the marketing performance and the financial performance (Bavarsad et al., 2013), strategic supplier partnership has a significant relationship with the competitive advantage of the firm in terms of delivery to market and time to market (Noraini et al., 2014), strategy development flexibility has a significant and strong positive impact on the customer satisfaction (Manders, 2009), the integration of the supply chain strategy with the organizational strategy is important to create the competitive advantage and to enhance the organizational performance (IshtiaqIshaq et al., 2012), the companies which have a high level of maturity in the SCM showed low level of the volatility in the financial performance (Venus, 2014). Based on these results that found information dissemination dimension only out of four dimensions of the (SC) construct is positively related to the all dimensions of the $(\mathrm{OIC})$ construct, therefore depending on these results, the hypothesis $\left(\mathrm{H}_{5}\right)$ is rejected.

\section{Conclusion}

This research underlines the test and the support of the theoretical framework of the (SCMC) constructs including outside-in process capabilities (OIC), inside-out process capabilities (IOC) and spanning process capabilities (SC) and their impact on business performance as proposed by Day (1994) and confirmed by (Tracey et al.,2004; Tracey et al., 2005). After presenting a brief literature review on the (SCMC) constructs and the business performance construct, the data was collected through a questionnaire which was administrated to a total sample of 250 managers in some companies belonging to three types of Egyptian industrial sector. The significant findings of this research, based on the regression analysis methods, can be highlighted as follows; the empirical analysis revealed that three dimensions of the (OIC) construct named as inbound transportation, material warehousing and inventory control-inbound have a strong positive relationship and contribute to explain the variance of all the dimensions of the (IOC) construct in contrast to the product support dimension. These results are consistent with the previous studies such as (Tseng et al., 2005; Rodrigues et al., 2008; Dimitrios, 2008; Ng'ang'a, 2013; Ann I et al., 2014). All the four dimensions of the (SC) construct (purchasing, customer order processing, strategy development and information dissemination) have a strong positive relationship and contribute to explain the variance of all the dimensions of the (IOC) construct. These results are consistent with the previous studies such as (Tracey et al., 2005; Carr et al., 2007; Arshinder et al., 2008; Fantazy et al., 2009; Prajogo et al., 2012; Sukati et al., 2013; Noraini et al., 2014). The analysis showed that purchasing dimension explains the lowest percentage of variance of all the dimensions of the (OIC) construct which is consistent with (Paulraj et al., 2007; Knight et al., 2008; Lawson et al., 2009; Kadima et al., 2013). The analysis showed that information dissemination, and customer order processing dimensions of the (SC) construct have a strong positive relationship and contribute to explain the variance of all the dimensions of the (OIC) construct. These results are consistent with the previous studies such as (Sundram et al., 2011; Meisel et al., 2011; Noraini et al., 2014) in contrast to the strategy development dimension. The analysis of the research found that all the dimensions of the (IOC) construct have a strong positive relationship with all the dimensions of the (BP); particularly, the outbound transportation dimension explains the highest percentage of the variance of the (BP) construct. These results are consistent with (Tracey et al., 2005; Green Jr et al., 2008; Meisel et al., 2011; Mekel 
et al., 2014). The analysis revealed that the packing dimension in the (IOC) construct has a positive relationship with all the dimensions of the (BP) construct, but explains the lowest percentage of the variance of the (BP) construct. This finding is consistent with (Tracey et al., 2005; Azad et al., 2013; Chaudhary, 2014; Wang et al., 2014). The analysis found that the information dissemination dimension out of the four dimensions of the (SC) construct has a positive relationship with all the dimensions of the (PB) construct and explains the variance of the (BP) construct. The results revealed that the purchasing, customer order processing and strategy development of the (SC) construct didn't explain any variance of the (PB) construct. These results are not consistent with the previous studies such as (Tracey et al., 2005; Trkman et al., 2006; Tutuncu et al., 2008; Lee et al., 2009; Cook et al., 2011; Prajogo et al., 2012; kumar et al., 2013; Noraini et al., 2014).

The research concluded that Egyptian companies face a number of challenges to implement the (SCMC) constructs in order to influence the business performance. These include low levels of attention from the managers of these companies to the importance of the production support system, political interference in (SCM) practices in developing strategies, in selecting the suppliers, in determining the quality level or the price of items purchased, In addition, inadequate customer order processing and inappropriate understanding issues related to how satisfying their customers, low levels of marketing performance, low interest toward achieving customer loyalty, and low levels of customer awareness towards perceiving the value of their products. These challenges may be considered as a result of the Arab Spring and given the substantial levels of political and social uncertainty and the forecasts have seen for 2011 sharply reduced in its economic growth, particularly, when the IMF published projections from September 2011, about the lower level of Egyptian economic growth with more than 4 percentage points to 12 points because of sharp declines with (-11.4) percent in its expenditures in both investment and manufacturing areas due to the cancelation or postponement of investments, the temporary closure of a number of factories and shops and the expectation of the continuous decline in the rate of the economic growth due to the political transition process that taking place in Egypt now (O'Sullivan, Rey, \& Mendez, 2012).

While the current study provides a contribution to researchers and practitioners in this area, there are still limitations. The precise effect of supply chain management capabilities (SCMC) on business performance is a multi-faceted and intricate issue, but this research interested only on the model's constructs and all its components as developed by (Tracey et al., 2005). The hypotheses were tested based on using regression analysis methods only to test the effects of each construct of the (SCMC) on the construct of business performance. This research was implemented on three types of the Egyptian industrial sector, so the results can't be generalized on other industrial sectors.

Future studies can examine the proposed relationships by bringing some contextual variables into the model, such as cross-functional teams, competition capabilities, green supply chain practices, resource sharing; thus providing a more coherent understanding of the relationship between (SCMC) and business performance. Future research should also use Structural Equation Model to test the direct and indirect effects of each dimension of SCMC on each dimension of firm performance. An integrated perspective is required for future research where the interrelation of the dimensions need to be investigated much further. The need to repeat this study in one or more other countries to retest the investigated the constructs of supply chain management capabilities and its impact on the construct of business performance and possibly support it with more evidence, and to help determine if the constructs are culturally robust. Further research should replicate this conceptual framework in other types of industrial sector.

\section{References}

Abdalkrim, G. M., \& AL-Hrezat, R. S. (2013). The Role of Packaging in Consumer's Perception of Product Quality at The Point of Purchase. European Journal of Business and Management, 5(4).

Ai-Chin, T., Abdul Hamid, A. B., Hon-Tat, H., Baharun, R., Yusoff, R. M. D., \& Rasli, A. (2011). The Proposed Conceptual Model for Investigating Moderating Effects of Contextual Factors on Supply Chain Management Practice-Performance Link in Malaysian Small and Medium Enterprises. International Journal of Business and Management, 6(12). http://dx.doi.org/10.5539/ijbm.v6n12p135

Ann I, O., Victoria, O. I., \& Ukpere, W. I. (2014). The Impact of Effective Inventory Control Management on Organisational Performance: A Study of 7up Bottling Company Nile Mile Enugu Nigeria. Mediterranean Journal of Social Sciences, 5(10). http://dx.doi.org/10.5901/mjss.2014.v5n10p109

Arshinder, K. A., \& Deshmukh, S. G. (2008). Supply chain coordination: Perspectives, empirical studies and research directions. International Journal of Production Economics, 115(2), 316-335. 
Augustine, A. N., \& Agu, A. O. (2013). Effect of Inventory Management on Organisational Effectiveness. Information and Knowledge Management, 3(8).

Azad, N., \& Mohammadi, M. (2013). An Empirical Survey on Factors Influencing on Packaging Dairy Products. Management Science Letters, 3, 1901-1906. http://dx.doi.org/10.5267/j.msl.2013.06.039

Baker, P. (2007). An Exploratory Framework of the Role of Inventory and Warehousing in International Supply $\begin{array}{llll}\text { Chains. International Journal of Logistics Management, } & \text { 18(1), }\end{array}$ http://dx.doi.org/10.1108/09574090710748171

Bavarsad, B., Azizi, A. D., \& Alesadi, F. J. (2013). Study of Relationship between Supply Chain Management Strategy with Logistics Performance and Organizational Performance. Interdisciplinary Journal of Contemporary Research in Business, 4(9).

Blomqvist, T. (2010). A Warehouse Design Framework for Order Processing and Materials Handling Improvement-Case Etra Oy. Master Dissertation, Department of Business Technology, Aalto University.

Carr, A. S., \& Kaynak, H. (2007). Communication Methods, Information Sharing, Supplier Development and Performance: An Empirical Study of Their Relationships. International Journal of Operations \& Production Management, 27(4), 346-370. http://dx.doi.org/10.1108/01443570710736958

Chaudhary, S. (2014). The Role of Packaging in Consumer's Perception of Product Quality. International Journal of Management and Social Sciences Research, 3(3).

Chen, C. Y., Leu, J. D., \& Chiou, C. H. (2006). The Impact of E-Supply Chain Capability on Competitive Advantage and Organizational Performance. International Journal of Electronic Business Management, $4(5), 419-427$.

Chow, H. K. H., Choy, K. L., Lee, W. B., \& Lau, K. C. (2006). Design of a RFID Case-Based Resource Management System for Warehouse Operations. Expert Systems with Applications, 30, 561-576. http://dx.doi.org/10.1016/j.eswa.2005.07.023

Cook, L. S., Heiser, D. R., \& Sengupta, K. (2011). The Moderating Effect of Supply Chain Role on The Relationship between Supply Chain Practices and Performance: An Empirical analysis. International Journal of Physical Distribution \& Logistics Management, 41(2), 104-134. http://dx.doi.org/ 10.1108/09600031111118521

Council of Supply Chain Management Professional Conferences (CSCMP's). (2013). 10 Practical Ways to Reduce Warehousing Costs. Annual Global Conference, October 20-23, at the Colorado Convention Center in Denver, CO. Retrieved from http://www.allieddistribution.com/article/3654-10-practical-ways-to-reduce-warehouse-costs

Day, G. S. (1994). The capabilities of market-driven organizations. Journal of Marketing, 58(4), 37-52. http://dx.doi.org/10.2307/1251915

Dhurup, M., Mafini, C., \& Dumasi, T. (2014). The Impact of Packaging, Price and Brand Awareness on Brand Loyalty: Evidence From the Paint Retailing Industry. AOSIS Open Journals, 14(1). http://dx.doi.org/10.4102/ac.v14i1.194

Dimitrios, P. (2008). The Effect of Inventory Management on Firm Performance. International Journal of Productivity and Performance Management, 57. http://dx.doi.org/10.1108/17410400810881827

Elkhouly, M. E., Ismail, S. E. D., Husien, G., \& El Shazely, S. E. S. (2012). Examining Supply Chain Practice in Egyptian SME Firms. Global Advanced Research, Journal of Management and Business Studies, 1(3), 070-074, April.

Fantazy, K., Kumar, V., \& Kumar, U. (2009). An Empirical Study of the Relationships Among Strategy, Flexibility and Performance in The Supply Chain Context. Supply Chain Management: An International Journal, 14(3), 177-188. http://dx.doi.org/10.1108/13598540910954520

Florian, G. L., \& Constangioara, A. (2013). The Impact of Performances in Romanian Supply Chains Organizational Performances. New Management for the New Economy, Proceedings of the $7^{\text {th }}$ International Management Conference, Bucharest, Romania.

Flynn, B. B., Huo, B., \& Zhao, X. (2010). The Impact of Supply Chain Integration on Performance: A Contingency and Configuration Approach. Journal of Operations Management, 28, 58-71. http://dx.doi.org/10.1016/j.jom.2009.06.001 
Giovanni, P. D. (2009). The Knowledge Manager's Role and Tasks for Supply Chain Management Success. Journal of Knowledge Management Practice, 10(1), 1-15.

Green Jr, K. W., Whitten, D., \& Inman, R. A. (2008). The Impact of Logistics Performance on Organizational Performance in a Supply Chain Context. Supply Chain Management: An International Journal, 13(4), 317-327. http://dx.doi.org/10.1108/13598540810882206

Gu, J., Goetschalckx, M., \& McGinnis, L. (2007). Reasearch on Warehouse Operation: A Comprehensive Review. European Journal of Operational Research, 177(1), 1-21. http://dx.doi.org/10.1016/j.ejor.2006.02.025

Hair, J. F., Anderson, R. E., Tatham, R. L., \& Black, W. C. (1998). Multivariate Data Analysis (5th ed.). New York: Macmillan Publishing Company.

Hamzeh, F. R., Tommelein, D. I., Ballard, G., \& Kaminsky M P. (2007). Logistics Centers To Support Project Based Production In The Construction Industry. Proceedings IGLC-15, July, Michigan, USA, 181-191.

Hans-Otto G. U. (2009). Operative Transportation Planning in Consumer Goods Supply Chains. Logistics Management Conference, Institute of Information Systems, University of Hamburg, Germany, 2-4, September.

Herrera, S., Selim, H., \& Zaki, H. Y. C. (2011). Egypt beyond the Crisis Medium-Term Challenges for Sustained Growth. The Economic Research Forum. Working Paper 625, September.

Hult, G. T., Ketchen JR, D, J., \& Arrfelt, M. (2007). Strategic Supply Chain Management: Improving Performance through a Culture of Competitiveness and Knowledge Development. Strategic Management Journal, 28, 1035-1052. http://dx.doi.org/10.1002/smj.627

IshtiaqIshaq, M., Khaliq, W., Hussain, N., \& Waqas M. (2012). A Review on Triple-A Supply Chain Performance. East Asian Journal of Business Management, 2(2), 35-39. http://dx.doi.org/10.13106/eajbm

Kadima, Z. R., Douglas, M., Kibet, Y., \& Manase, G. W. (2013). An Analysis of Procurement Procedures on the Implementation of Government Construction Projects in Kenyan Public Universities: Case Study of Masinde Muliro University. 1st JKUAT-SHRD Research Conference, $12^{\text {th }}-13^{\text {th }}$, September.

Kamel, A. F., Vinod, K., \& Uma, K. (2010). Supply Management Practices and Performance in the Canadian Hospitality Industry. International Journal of Hospitality Management, 29(4), 685-693. http://dx.doi.org/10.1016/j.ijhm.2010.02.001.

Kempkes, J. P., Koberstein, A. A., \& Suhl, L. (2010). A Resource Based Mixed Integer Modelling Approach for Integrated Operational Logistics Planning. Advanced Manufacturing and Sustainable Logistics, Lecture Notes in Business Information Processing, 46, 281-294.

Knight, L. A., Harland, C. M., Telgen, J., Thai, K. V., \& Callender, G. (2008). Public Procurement: International Cases and Commentary. London, UK: Routledge.

Kotzab, B., Teller, C., Grant, D. B., \& Friis, A. (2014). Supply Chain Management Resources, Capabilities and Execution. Journal of Production Planning \& Control. http://dx.doi.org/10.1080/09537287.2014.927932.

Kumar, C. G., \& Nambirajan, T. (2014). Direct and Indirect Effects: SCM Components. SCMS Journal of Indian Management, A Quarterly Journal, 11(1), 51-63.

kumar, G. C., \& Nambirajan, T. (2013). Supply Chain Management Components, Competitiveness and Organisational Performance: Causal Study of Manufacturing Firms. Asia-Pacific Journal of Management Research and Innovation, 399-412. http://dx.doi.org/10.1177/2319510X14523109.

Lawson, B., Cousins, P. D., \& Handfield, R. B. (2009). Strategic Purchasing, Supply Management Practices and Buyer Performance Improvement: An Empirical Study of UK Manufacturing Organisations. International Journal of Production Research, 47(10), 2649-2667. http://dx.doi.org/10.1080/00207540701694313

Lawson, B., Cousins, P. D., Handfield, R. B., \& Petersen, K. J. (2009). Strategic Purchasing, Supply Management Practices and Buyer Performance Improvement: An Empirical Study of UK Manufacturing Organisations. International Journal of Production Research, 47(10), 2649-2667. http://dx.doi.org/10.1080/00207540701694313.

Lee, H., \& Whang, S. (2009). Information Sharing in a Supply Chain. International Journal of Technology Management, 20(3-4). http://dx.doi.org/10.1504/IJTM.2000.002867 
Lee, S.S., Jang, H W., Kim, S., Kim, J. W., \& Lee, H. (2008). A Study on Relationship between Supply Chain Structure and SCM Activities: An Empirical Test in Korea. International Journal of Business Research, 8(4), 138-144.

Li, S., Ragu-Nathanb, B., Ragu-Nathanb, T. S., \& Rao, S. S. (2006). The Impact of Supply Chain Management Practices on Competitive Advantage and Organizational Performance. Omega-International Journal of Management Science, 34(2), 107-124. http://dx.doi.org/10.1016/j.omega.2004.08.002

Lockamy, A., \& McCormack, K. (2004). Linking SCOR Planning Practices to Supply Chain Performance: An Exploratory Study. International Journal of Operations \& Production Management, 24(12), 1192-1218. http://dx.doi.org/10.1108/01443570410569010

Lwiki, T., Ojera, P. B., Mugenda, N. G., \& Wachira, V. K. (2013). The Impact of Inventory Management Practices on Financial Performance of Sugar Manufacturing Firms in Kenya. International Journal of Business, Humanities and Technology, 3(5).

Management \& Development Center. (2011). Fundamental Contradictions which Distort the Performance of the State Administrative Apparatus. Retrieved from http://www.mdcegypt.com

Manders, J. (2009). Supply Chain Flexibility Aspects and Their Impact on Customer Satisfaction. Master of Supply Chain Management, Open University the Netherlands.

Martin, P. R., \& Patterson, J. W. (2009). On Measuring Company Performance within A Supply Chain. International Journal of Production Research, 47(9), 2449-2460. http://dx.doi.org/10.1080/00207540701725604

Mathuva, D. (2013). Determinants of Corporate Inventory Holdings: Evidence from a Developing Country. The International Journal of Applied Economics and Finance, 7, 1-22. http://dx.doi.org/10.3923/ijaef.2013.1.22

Meisel, F., Rei, W., Gendreau, M., \& Bierwirth, C. (2011). The Design of Supply Networks Under Maximum Customer Order Lead Times. Interuniversity Research Centre on Enteprise Networks, Logistics and Transportation (CIRRELT), September.

Mekel, C., Anantadjaya, S. P. D., \& Lahindah, L. (2014). Stock Out Analysis: An Empirical Study on Forecasting, Re-Order Point and Safety Stock Level at PT Combiphar, Indonesia. RIBER: Review of Integrative Business and Economics Research, 3(1).

Mogere, K. M., Oloko, M., \& Okibo, W. (2013). Effect Of Inventory Control Systems on Operational Performance of Tea Processing Firms: A Case Study of Gianchore Tea Factory, Nyamira County, Kenya. The International Journal Of Business \& Management, 1(5), November.

Mukai, S. (2014). Analysis of Common Cognition of Impression among Japanese Fonts and Tea Beverage Packaging. International Conference on Kansai Engineering and Emotion Research, June.

Muzumdar, M., \& Zinzuwadia, A. (2013). Secrets to Successful Order Fulfillment. Supply Chain Management Review, 40-45.

Naude, M. J., \& Badenhorst-Weiss, J. A. (2011). Supply Chain Management Problems at South African Automotive Component Manufacturers. Southern African Business Review, 15(1).

Ng'ang'a, K. J. (2013). An Assessment of the Factors Influencing Effectiveness of Inventory Control. International Journal of Business and Commerce, 3(1).

Noor, N., Saeed, R., \& Lodhi, R. N. (2013). Factors Affecting Supply Chain Management Effectiveness: A Case of Textile Sector of Pakistan. Journal of Basic and Applied Scientific Research, 3(11), 56-63.

Noraini, A., \& Saifudin, A. M. (2014). Supply Chain Management in Telecommunication Industry: The Mediating Role of Logistics Integration. International Conference of Technology and Operations Management (ICTOM), At Putera World Trade Centre (PWTC), Kuala Lumpur, Malaysia.

O'Sullivan, A., Rey, M. E., \& Mendez, J. G. (2011). Opportunities and Challenges in the MENA Region. Arab World Competitive Report, 1-27.

Paulraj, A., Chen, I. J., \& Flynn, J. (2007). Levels of strategic purchasing: Impact on supply integration and performance. Journal of Purchasing and Supply Management, 12(3), 107-122. http://dx.doi.org/10.1016/j.pursup.2006.08.002

Perry, C. (2012). The Impact of Supply Chain Business Processes on Competitive Advantage and Organizational Performance. Master Dissertation, Department of Operational Sciences, Air University. 
Prajogo, D., \& Olhager, J. (2012). Supply Chain Integration and Performance: The Effects of Long-Term Relationships, Information Technology and Sharing, and Logistics Integration. International Journal Production Economics, 135(1), 514-522. http://dx.doi.org/10.1016/j.ijpe.2011.09.001

Rodrigues, V. S., Stantchev, D., Potter, A., Naim, M., \& Whiteing, A. (2008). Establishing a Transport Operation Focused Uncertainty Model For The Supply Chain. International Journal of Physical Distribution \& Logistics Management, 38(5), 388-411. http://dx.doi.org/10.1108/09600030810882807

Rumanathan, U. (2014). Performance of Supply Chain Collaboration-A Simulation Study. Expert Systems with Applications: An International Journal, 41(1), 210-220. http://dx.doi.org/10.1016/j.eswa.2013.07.022

Sengupta, K., Heiser, D. R., \& Cook, L. S. (2006). Manufacturing and Service Supply Chain Performance: A Comparative Analysis. Journal of Supply Chain Management, 42(4), 4-15. http://dx.doi.org/10.1111/j.1745-493X.2006.00018.x

Shang, K. C., \& Marlow, P. B. (2005). Logistics Capability and Performance in Taiwan's Major Manufacturing Firms. Transportation Research Part E, 41(3), 217-234. http://dx.doi.org/10.1016/j.tre.2004.03.002

Silayoi, P., \& Speece, M. (2007). The Importance of Packaging Attributes: A Conjoint Analysis Approach. European Journal of Marketing, 41(11/12). http://dx.doi.org/10.1108/03090560710821279

Stadtler, H. (2005). Supply Chain Management and Advanced Planning-Basics, Overview and Challenges. European Journal of Operational Research, 163, 575-588. http://dx.doi.org/10.1016/j.ejor.2004.03.001

Sukati, I., Abdul Hamid, A. B., \& Baharun, R. (2013). Testing the Effect of the Supply Chain Management Implementation on Business Performance: An Empirical Study. International Business Research, 6(1). http://dx.doi.org/10.5539/ibr.v6n1p76

Sukati, I., Abdul Hamid, A. B., Baharun, R., Tat, H. H., \& Said, F. (2011). An Investigation of the Relationship between Supply Chain Management Practices and Competitive Advantage of the Firm. Contemporary Marketing Review, 1(4), 1-13.

Tracey, M. (2003). An empirical study of the interaction among inbound and outbound transportation, delivery service, and manufacturing firm performance. 14th Annual North American Research/Teaching Symposium on Purchasing and Supply Chain Management (pp. 549-568).

Tracey, M., Fite, R. W., \& Sutton, M. J. (2004). An Explanatory Model and Measurement Instrument: A Guide to Supply Chain Management Research and Applications. American Journal of Business, 19(2). http://dx.doi.org/10.1108/19355181200400012

Tracey, M., Lim, J. S., \& Vonderembse, M. A. (2005). The impact of supply-chain management capabilities on business performance. Supply Chain Management: An International Journal, 10(3), 179-191. http://dx.doi.org/10.1108/13598540510606232

Trkman, P., \& Groznik, A. (2006). Measurement of Supply Chain Integration Benefits. Interdisciplinary Journal of Information, Knowledge, and Management, 1, 37-47. http://dx.doi.org/10.1.1.381.7030

Tseng, Y. Y., Taylor, M. A. P., \& Yue, W. L. (2005). The Role of Transportation in Logistics Chain. Proceedings of the Eastern Asia Society for Transportation Studies, 5, 1657-1672.

Tutuncu, O., \& Kucukusta, D. (2008). The Role of Supply Chain Management Integration in Quality Management System for Hospitals. International Journal of Management Perspectives, 1(1), 31-39.

Van Weele, A. J., \& Van Raaij, E. M. (2014). The Future of Purchasing and Supply Management Research: About Relevance and Rigor. Journal of Supply Chain Management, 50(1), 56-72. http://dx.doi.org/10.1111/jscm.12042

Venus, K. (2014). Supply Chain Management-Part of Strategic Management. Journal of Business and Economics, 5(7), 1052-1067. http://dx.doi.org/10.15341/jbe(2155-7950)/07.05.2014/010

Wahome, P. W. (2013). Factors Influencing Inventory Management in Public Sector: A Case Study of THE Othaya District Hospital. First SHRD Annual Research Conference, 12th and 13th, September.

Wang, J., Hong, X., Qian, Y., Wang, Z. W., \& Lu, L. X. (2014). Inverse Sub-Structuring Method for Multi-Coordinate Coupled Product Transport System. Packing Technology and Science: An International Journal, 27(5), 385-408. http://dx.doi.org/10.1002/pts.2035 
Whitten, G. D., Green, K. W. J., \& Zelbst, P. J. (2012). Triple-A Supply Chain Performance. International Journal of Operations \& Production Management, 32(1), 28-48. http://dx.doi.org/10.1108/01443571211195727

Wisner, J. D. (2003). A Structural Equation Model of Supply Chain Management Strategies and Firm $\begin{array}{lllll}\text { Performance. Journal of } & \text { Business } & \text { Logistics, } & 24(1), & 1-26 .\end{array}$ http://dx.doi.org/10.1002/j.2158-1592.2003.tb00030.x

Zailani, S., Dahalan, N., Hamdani, Y., \& Fernando, Y. (2009). Supply Chain Technology: An Empirical Study in The Context of Malaysia. 9th Asia Pasific Industrial Engineering \& Management Systems Conference, December.

Zhang, J. Q., Dixit, A., \& Friedmann, R. (2010). Customer Loyalty and Lifetime Value: An Empirical Investigation of Consumer Packaged Goods. Journal of Marketing Theory Practice, 18(2), 127-139. http://dx.doi.org/10.2753/MTP1069-6679180202

Zhang, Q., Vonderembse, M. A., \& Lim, J. S. (2006). Spanning Flexibility: Supply Chain Information Dissemination Drives Strategy Development and Customer Satisfaction. Supply Chain Management: An International Journal, 11(5), 390-399. http://dx.doi.org/10.1108/13598540610682408

\section{Copyrights}

Copyright for this article is retained by the author(s), with first publication rights granted to the journal.

This is an open-access article distributed under the terms and conditions of the Creative Commons Attribution license (http://creativecommons.org/licenses/by/3.0/). 